\title{
An Assessment of Energy Potential at Non-Powered Dams in the United States
}

Boualem Hadjerioua, Principal Investigator

Yaxing Wei and Shih-Chieh Kao

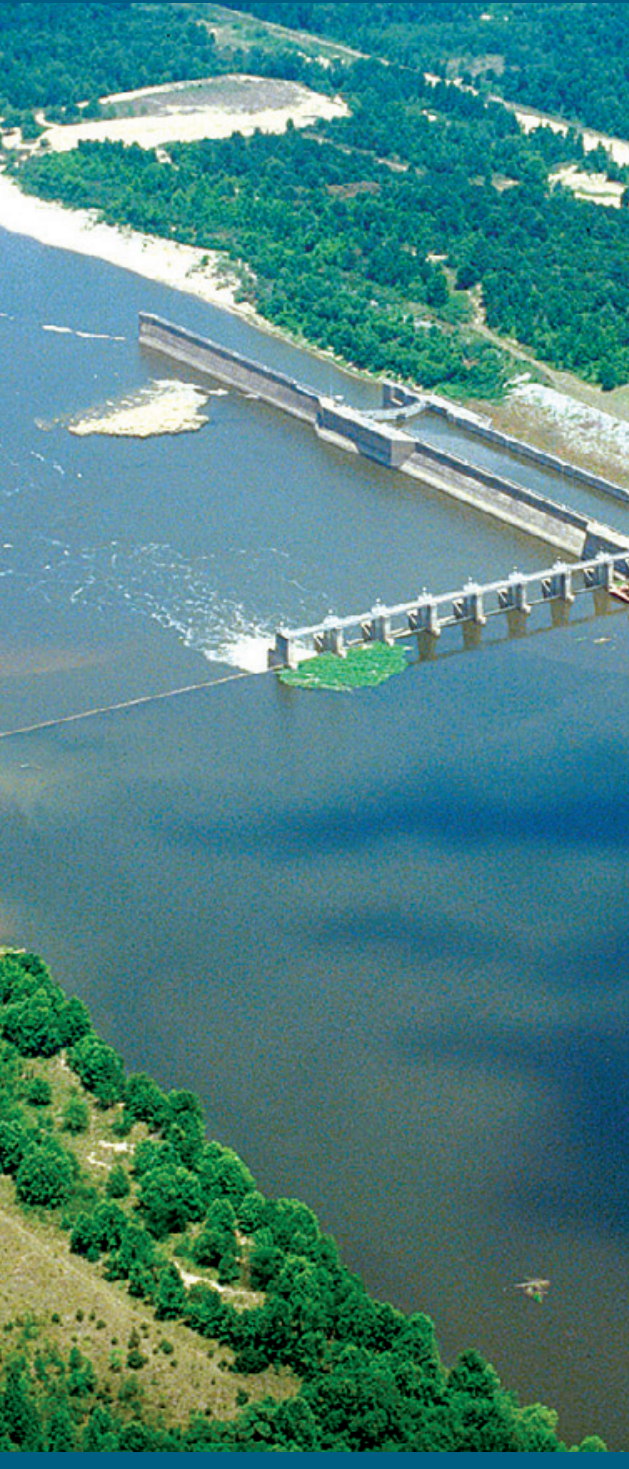

Prepared for

the U.S. Department of Energy

Wind and Water Power Program

Budget Activity Number ED 1907042

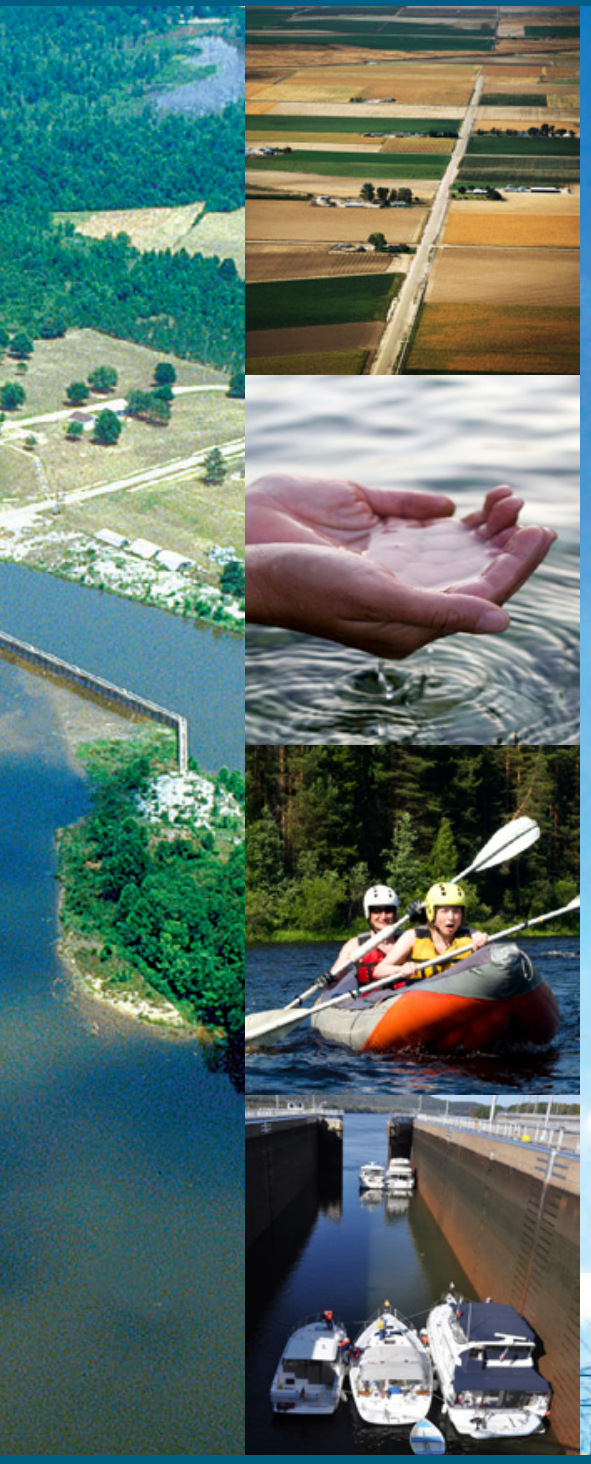

Prepared by

OAK RIDGE NATIONAL LABORATORY

Oak Ridge, Tennessee 37831

Managed by UT-BATTELLE, LLC

for the U.S. DEPARTMENT OF ENERGY

under contract DE-AC05-000R22725

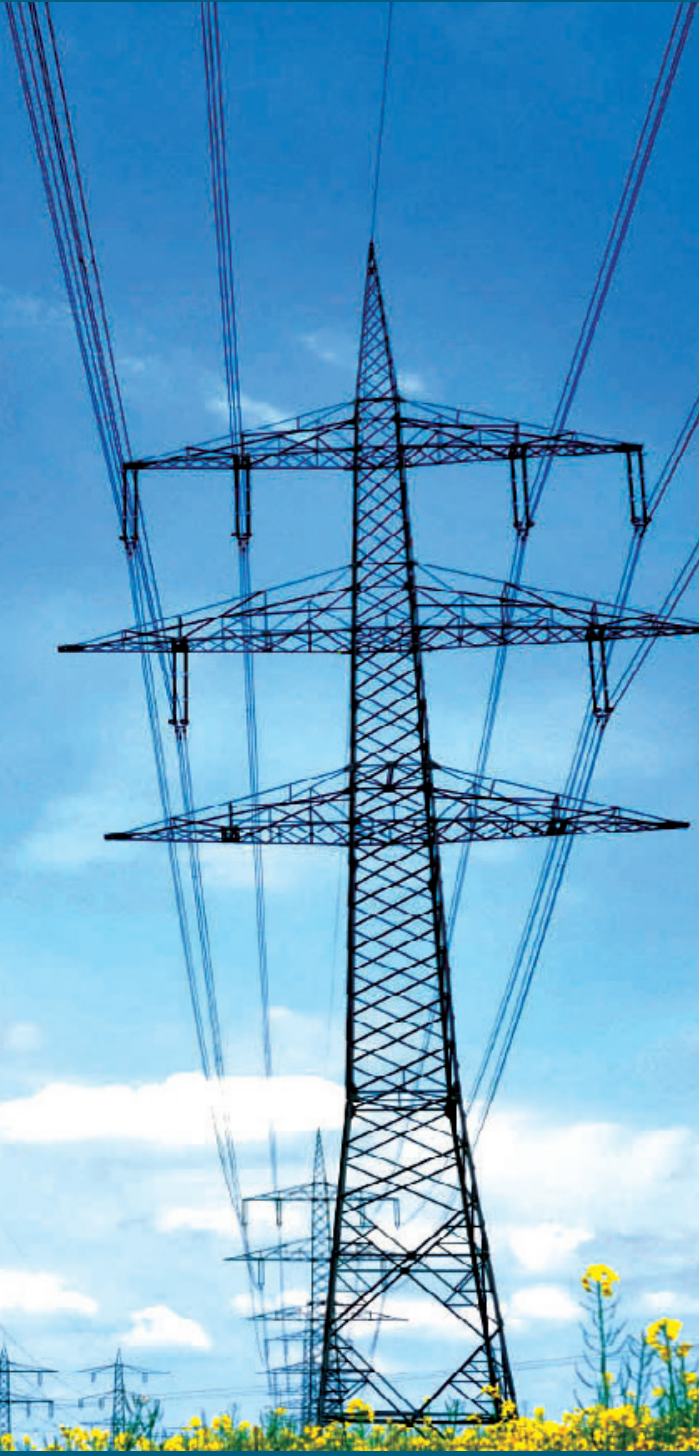

Report 


\title{
DOCUMENT AVAILABILITY
}

Reports produced after January 1, 1996, are generally available free via the U.S. Department of Energy (DOE) Information Bridge.

Web site http://www.osti.gov/bridge

Reports produced before January 1, 1996, may be purchased by members of the public from the following source.

\author{
National Technical Information Service \\ 5285 Port Royal Road \\ Springfield, VA 22161 \\ Telephone 703-605-6000 (1-800-553-6847) \\ TDD 703-487-4639 \\ Fax 703-605-6900 \\ E-mail info@ntis.fedworld.gov \\ Web site http://www.ntis.gov/support/ordernowabout.htm
}

Reports are available to DOE employees, DOE contractors, Energy Technology Data Exchange (ETDE) representatives, and International Nuclear Information System (INIS) representatives from the following source.

Office of Scientific and Technical Information

P.O. Box 62

Oak Ridge, TN 37831

Telephone 865-576-8401

Fax 865-576-5728

E-mail reports@adonis.osti.gov

Web site http://www.osti.gov/contact.html

This report was prepared as an account of work sponsored by an agency of the United States Government. Neither the United States Government nor any agency thereof, nor any of their employees, makes any warranty, express or implied, or assumes any legal liability or responsibility for the accuracy, completeness, or usefulness of any information, apparatus, product, or process disclosed, or represents that its use would not infringe privately owned rights. Reference herein to any specific commercial product, process, or service by trade name, trademark, manufacturer, or otherwise, does not necessarily constitute or imply its endorsement, recommendation, or favoring by the United States Government or any agency thereof. The views and opinions of authors expressed herein do not necessarily state or reflect those of the United States Government or any agency thereof. 


\section{An Assessment of Energy Potential at Non-Powered Dams in the United States}

\section{Boualem Hadjerioua, Principal Investigator}

Yaxing Wei and Shih-Chieh Kao

\section{Report}

Prepared for the

U.S. Department of Energy

Wind and Water Power Program

Budget Activity Number ED 1907042

Prepared by

OAK RIDGE NATIONAL LABORATORY

Oak Ridge, Tennessee 37831

Managed by

UT-BATTELLE, LLC

for the

U.S. DEPARTMENT OF ENERGY

under contract DE-AC05-00OR22725 


\section{Table of Contents}

\section{Page}

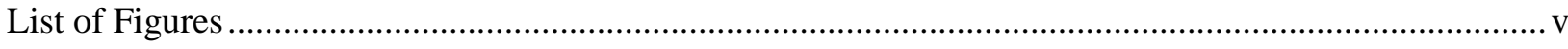

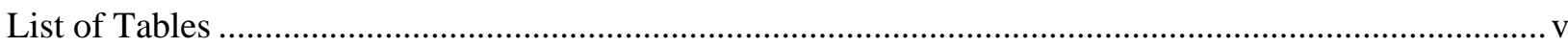

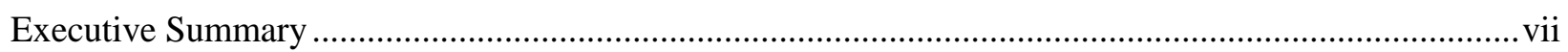

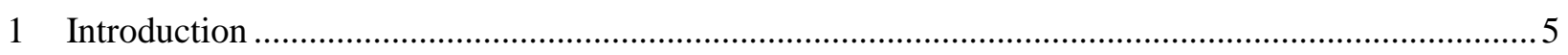

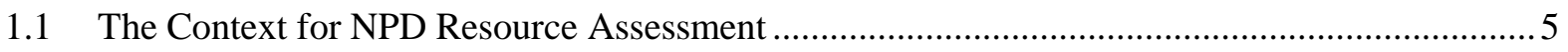

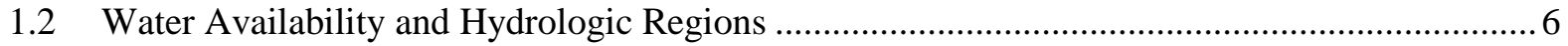

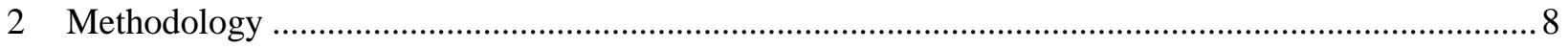

2.1 Energy Production Models for a Non-Powered Dam ............................................................. 8

2.2 Data Requirements and Sources for Nationwide Assessment of NPD Potential...................... 11

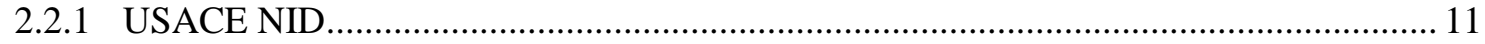

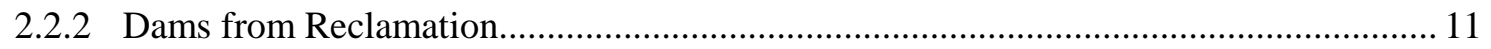

2.2.3 National Hydropower Asset Assessment Program (NHAAP) Baseline Database .......... 11

2.2.4 Natural Resources Conservation Service Watershed Boundary Dataset (WBD)............ 12

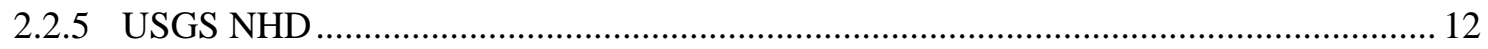

2.2.6 NHDPlus Version 1 from USGS and Horizon Systems Corporation ............................. 12

2.2.7 National Water Information System (NWIS) Gauge Observation from USGS .............. 12

2.3 Data Synthesis and Computation of Potential .................................................................... 12

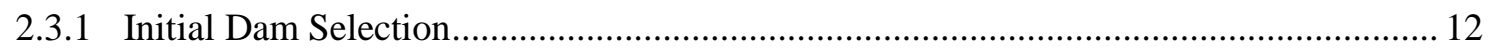

2.3.1.1 Update NID Dams Location Using NHD ....................................................... 12

2.3.1.2 Exclude Existing Powered Dams, Auxiliary Dams, and Low Head Dams.............. 13

2.3.1.3 Identification of Dams on Streams with Negligible Streamflow ........................... 13



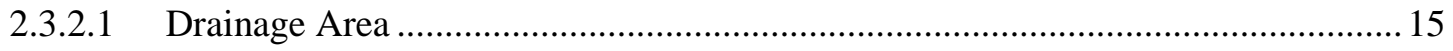

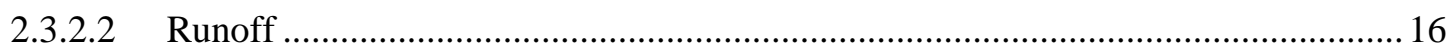

2.3.2.3 Streamflow Calculation and Selection ................................................................. 16

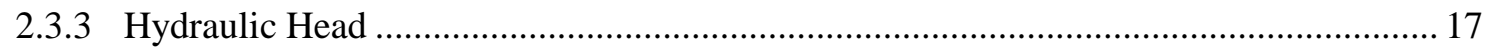

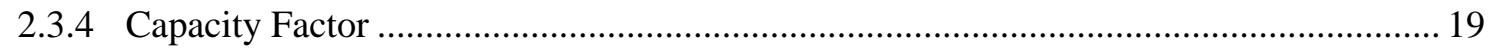

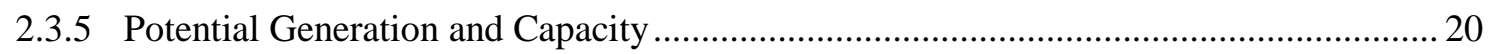

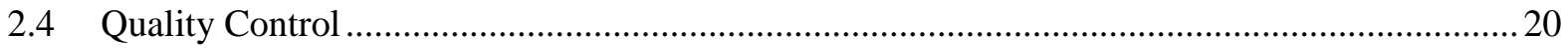

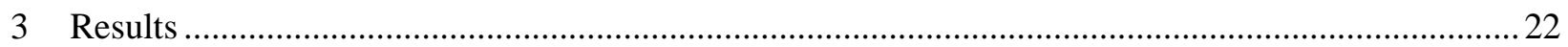

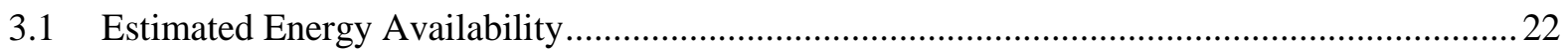

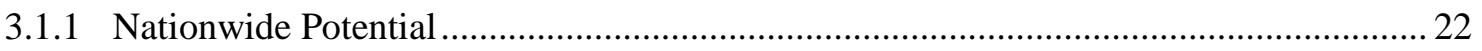

3.1.2 Regional Potential by River Basin and State............................................................. 24 
3.2 Integration with Existing Hydropower Inventory and Other Renewable Energy Facilities .......25

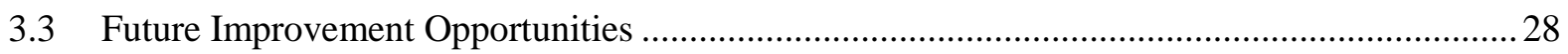

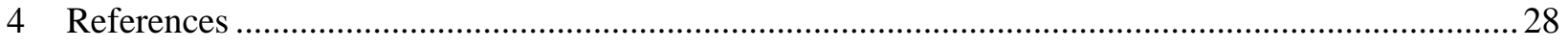

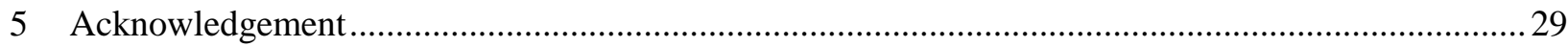

Appendix A. Top 100 NPD with Hydropower Potential ......................................................................... 31

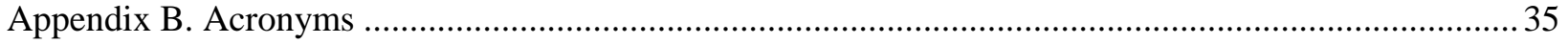




\section{List of Figures}

Page

Figure ES-1: Locations of the top non-powered dams with potential hydropower capacities greater than 1

MW. viii

Figure 1. The existing hydropower capacity within each hydrologic region (Source: National Hydropower

Asset Assessment Program Existing Hydropower Plant Summary, Hadjerioua et al., 2011)... 7

Figure 2. Approach to the NPD resource assessment .....

Figure 3. Illustration of the first criterion classification of DWNS - In this example, because the dam

"Vandiver Bros Lake" is close to NHD flowline but far from NHDPlus flowline, it is designated as located on segment with negligible streamflow.

Figure 4. Illustration of the second criterion for selecting DWNS - In this example, because the dam "Crane Lake" is not close to any NHD flowline or NHDPlus flowline, it cannot be linked to any stream and is designated as located on segment with negligible streamflow.

Figure 5. Illustration of linkage between NID and NHDPlus - In NID, Livingston Dam is linked to an NHDPlus flowline (in red color), which represents the Trinity River. The accumulative drainage area for this NHDPlus flowline is 16,572 square miles, which will be used as the dam's drainage area.

Figure 6. Illustration of runoff derivation 17

Figure 7. Monthly mean streamflow time series for John Sevier Dam, Tennessee .................................. 17

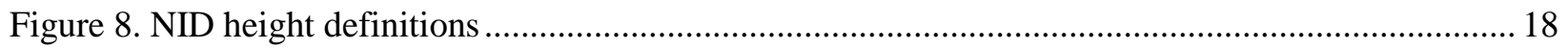

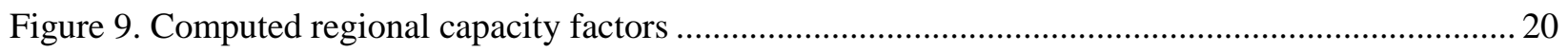

Figure 10. Cumulative potential capacity distribution of the top existing NPDs with the greatest potential added generation capacity 23

Figure 11. Location of the top NPDs with potential capacities greater than $1 \mathrm{MW}$................................24

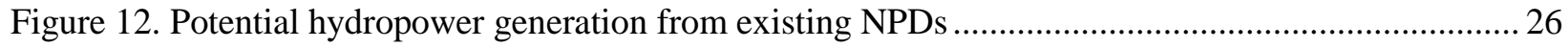

Figure 13. Comparison of NPD potential with wind and solar resource potential .................................. 27

\section{List of Tables}

Table 1. Mean Annual U.S. Water Availability from 1971-2008 ….................................................... 7

Table 2. Type of Heads Used to Estimate Potential Installed Capacity ................................................... 19

Table 3. Summary of NPD Assessment by Hydrologic Regions Totaling 12.1 GW of Potential ............. 25

Table 4. Summary of NPD Assessment by State Totaling 12.1 GW of Potential ...................................25 
This Page Intentionally Left Blank 


\section{Executive Summary}

The United States has produced clean, renewable electricity from hydropower for more than 100 years, but hydropower-producing facilities represent only a fraction of the infrastructure development that has taken place on the nation's waterways. In contrast to the roughly 2,500 dams that provide 78 gigawatts $(\mathrm{GW})^{1}$ of conventional and $22 \mathrm{GW}$ of pumped-storage hydropower, the United States has more than 80,000 non-powered dams (NPDs) — dams that do not produce electricity — providing a variety of services ranging from water supply to inland navigation. Importantly, many of the monetary costs and environmental impacts of dam construction have already been incurred at NPDs, so adding power to the existing dam structure can often be achieved at lower cost, with less risk, and in a shorter timeframe than development requiring new dam construction. The abundance, cost, and environmental favorability of NPDs, combined with the reliability and predictability of hydropower, make these dams a highly attractive source for expanding the nation's renewable energy supply.

To better characterize this unique national resource, the U.S. Department of Energy (DOE) Wind and Water Power Program has undertaken a national-scale analysis of U.S. dams to determine the ability of NPDs to provide hydroelectric power. DOE's Oak Ridge National Laboratory (ORNL), with input from DOE's Idaho National Laboratory, quantified the potential capacity and generation available from adding power production capability to U.S. NPDs. Of the more than 80,000 NPDs throughout the U.S., 54,391 dams were analyzed, with remaining dams eliminated from consideration due to erroneous geographic information, or erroneous flow or drainage area attributes that could not be resolved and corrected through independent investigation of maps and records. Anecdotal information suggests that these dams with missing or erroneous information are likely to be relatively small or have low potential to produce hydroelectric energy. Dams with a reported height of less than five feet were also excluded from analysis. A thorough quality control and review process ensured that the 54,391 remaining NPDs were analyzed and characterized as accurately as possible. Figure ES-1 demonstrates the spatial and capacity potential distribution of the nation's NPDs. Electric generating capacities included in the report were calculated using the assumption that all water passing a facility would be available for conversion into electrical energy and that hydraulic head at the facility would remain constant. The analysis did not consider the economic feasibility of developing each unpowered facility. The assessment provides preliminary information for stakeholders (such as developers, municipal planners, and policymakers), who can further evaluate the potential to increase hydropower production at NPD sites. Developers could use the information provided in this assessment to focus on more detailed analysis of sites that demonstrate a reasonable potential for being developed.

Adding power to U.S. NPDs has the potential to add up to $12 \mathrm{GW}(12,000$ megawatts or MW) of new renewable capacity - a potential equivalent to increasing the size of the existing conventional hydropower

\footnotetext{
${ }^{1} 1$ gigawatt $(\mathrm{GW})=1,000$ megawatts $(\mathrm{MW})$. On an annual basis, $1 \mathrm{MW}$ of hydropower produces enough electricity to power nearly 400 U.S. homes. Each gigawatt could power up to 400,000 homes.
} 
fleet by $15 \%$. A majority of this potential is concentrated in just 100 NPDs, which could contribute approximately $8 \mathrm{GW}$ of clean, reliable hydropower; the top 10 facilities alone could add up to $3 \mathrm{GW}$ of new hydropower. Eighty-one of the 100 top NPDs are U.S. Army Corps of Engineers (USACE) facilities, many of which, including all of the top 10, are navigation locks on the Ohio River, Mississippi River, Alabama River, and Arkansas River, as well as their major tributaries. This study also shows that dams owned by the U.S. Bureau of Reclamation hold the potential to add approximately $260 \mathrm{MW}$ of capacity; the Bureau has also engaged in an effort to conduct a more detailed evaluation of its own facilities.

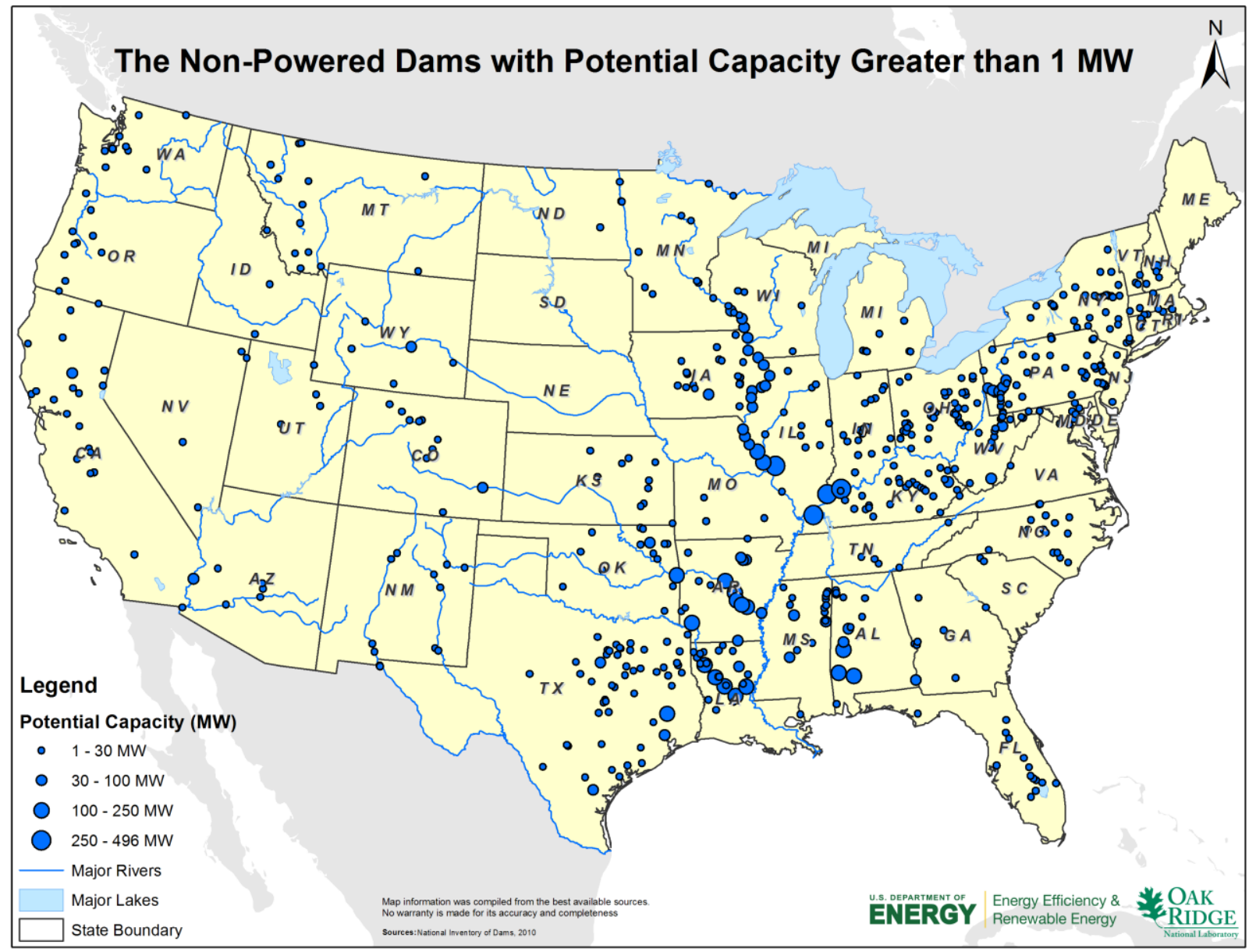

Figure ES-1: Locations of the top non-powered dams with potential hydropower capacities greater than 1 MW

For further information please contact:

Principal Investigator: Boualem Hadjerioua Oak Ridge National Laboratory

P.O. Box 2008, MS 6036

Oak Ridge, TN 37831

Phone: (865) 574-5191

E-mail: hadjeriouab@.ornl.gov
Program Manager: Brennan T. Smith

Water Power Technologies

Oak Ridge National Laboratory

P.O. Box 2008, MS 6036

Oak Ridge, TN 37831

Phone: (865) 241-5160

E-mail:smithbt@.ornl.gov 
This Page Intentionally Left Blank 


\section{Introduction}

This report describes a U.S. Department of Energy (DOE) Wind and Water Power Program study carried out by Oak Ridge National Laboratory (ORNL) with inputs from Idaho National Laboratory to assess the energy potential at non-powered dams (NPDs) throughout the United States. In this context, NPDs are dams that do not include hydraulic turbine (hydropower) equipment. Such dams were constructed for one or more non-energy benefits, including flood control, water supply, navigation, or recreation. Auxiliary dams that form parts of power-producing impoundments are not included in the NPD scope because the water they store already is associated with existing hydropower production.

This report addresses only the energy production potential of NPDs. The priority placed on this NPD assessment effort (relative to an assessment of energy potential from new impoundments, for example) is based on the hypothesis that many of the costs and environmental impacts of dam construction have already been incurred at NPDs and may not be significantly increased by the incorporation of new energy production facilities. Thus, the development of some NPD's for energy purposes is assumed to be achievable with lower installed cost, lower levelized cost-of-energy, fewer barriers to development, less technological and business risk, and in a shorter time frame than development requiring new dam construction. Future detailed studies of site-specific costs and impacts will be required to test this hypothesis. That is, the initial estimates of the number of developable NPDs and associated capacity additions will have to be refined with better information on such issues as environmental constraints (e.g., the environmental costs and benefits of changes in flow releases to optimize power production), dam integrity/safety issues, and multiple use conflicts.

NPDs in the United States range in size from small berms impounding farm ponds to large Ohio River and Mississippi River dams that pool water to maintain navigation depths during low-flow periods. The National Inventory of Dams (NID) includes more than 80,000 dams with physical heights ranging from about 4 feet to 770 feet. This study analyzed a subset of 54,391 NPDs with monthly average flows ranging from about 1 cubic feet per second (cfs) to 68,500 cfs.

\subsection{The Context for NPD Resource Assessment}

The assessment activities reported herein were aimed at quantifying, with a useful degree of certainty, the aggregated national, regional, and basin-scale added capacity and generation potential for NPDs. NPDs are one of several resource classes to be examined in the DOE Hydropower Resource Assessment. Additional resource classes include the following:

- Increased capacity and generation at existing powered facilities through unit upgrades, minimum flows units or additional units.

- New capacity from constructed waterways, such as irrigation canals and municipal water systems.

- New capacity and storage from new sustainable hydropower sites.

Each site considered for upgrade or new development in any of these resource classes has a set of cost, socioeconomic impact, and environmental impact attributes that have influenced and will influence the 
hydropower development and regulatory decisions for that site. This initial report on NPD potential does not address these costs and impacts. Development also is influenced by energy prices in different regions of the United States along with other incentives, such as state programs that provide tax credits or renewable energy credits.

At national and regional scales (the focus of this initial report), the geospatial databases included in the assessments reported herein enable automated analyses and aggregation of site potentials according to explicit rules. These rules include geo-registration to assign a dam to a specific stream segment, estimation of seasonal and monthly water availability, estimation of hydraulic head, and estimation of a capacity factor to determine rated capacity from annual production. Such rules engender assumptions, approximations, and uncertainty that render results that are only appropriate for reconnaissance-level studies of hydropower development.

In contrast to site-specific studies that would support project design, feasibility, and due-diligence studies for project development financing, the focus of these national- and regional-scale studies is to provide high-level summary statistics of the availability of hydropower resources. Avoidance of systematic processing errors that overestimate or underestimate aggregate national and regional energy and capacity statistics is a key concern. Conversely, uncertainty in the capacity and energy production estimates for individual sites (i.e., from relying on remote-sensing data and maps rather than "boots on the ground" observations of conditions) is problematic only if it biases trends among technology classes or geographic regions.

The availability and enhancement of national-scale datasets, such as NID and the National Hydrography Dataset (NHD), provide a foundation for rigorous estimates of NPD potential for production for the entire country. Previous assessments - including Hall et al. (2004), U.S. Department of Interior (DOI) et al. (2007), and U.S. Bureau of Reclamation (2011) — have also been consulted in preparing the estimates reported herein.

\subsection{Water Availability and Hydrologic Regions}

Water availability, along with physical relief, is the primary determinant of energy potential. It varies significantly among different geographical regions in the United States. To help understand our current resources at a regional level, Table 1 summarizes data for two important hydrologic variables, precipitation (P) and runoff $(\mathrm{Q})$, and the $\mathrm{Q} / \mathrm{P}$ ratios for the years 1971-2008 for each of the 18 major hydrologic regions of the continental United States. Both $\mathrm{P}$ and $\mathrm{Q}$ are expressed in inches. The $\mathrm{Q} / \mathrm{P}$ ratio indicates the percent of precipitation that can eventually be utilized from streamflow after evapotranspiration, groundwater infiltration, and other internal hydrologic processes. Evaporation is believed to be the dominant factor affecting the $\mathrm{Q} / \mathrm{P}$ ratio. Although the $\mathrm{Q} / \mathrm{P}$ ratio does not directly contribute to the assessment of NPD potential, it can provide some background hydrologic understanding regarding the regional water availability that may be utilized for hydropower generation. For comparison, the existing hydropower capacity within each hydrologic region is illustrated in Figure 1. 
Table 1. Mean Annual U.S. Water Availability from 1971-2008

\begin{tabular}{llll|llll}
\hline $\begin{array}{l}\text { Hydrologic Regions } \\
\text { (HUC02) }\end{array}$ & $\begin{array}{l}\text { Precip. } \\
\mathrm{P}^{\mathrm{a}} \\
\text { (inch) }\end{array}$ & $\begin{array}{l}\text { Runoff } \\
\mathrm{Q}^{\mathrm{b}} \\
\text { (inch) }\end{array}$ & $\begin{array}{l}\text { Q/P } \\
\text { ratio } \\
(\%)\end{array}$ & $\begin{array}{l}\text { Hydrologic Regions } \\
\text { (HUC02) }\end{array}$ & $\begin{array}{l}\text { Precip. } \\
\mathrm{P}^{\mathrm{a}} \\
\text { (inch) }\end{array}$ & $\begin{array}{l}\text { Runoff } \mathrm{Q}^{\mathrm{b}} \\
\text { (inch) }\end{array}$ & $\begin{array}{l}\mathrm{Q} / \mathrm{P} \\
\text { ratio } \\
(\%)\end{array}$ \\
\hline 1 New England & 45.7 & 25.7 & 56.1 & 10 Missouri & 20.7 & 2.5 & 11.8 \\
2 Mid Atlantic & 44.2 & 20.3 & 46.1 & 11 Arkansas-White-Red & 31.7 & 2.9 & 9.1 \\
3 South Atlantic-Gulf & 52.1 & 17.2 & 33.1 & 12 Texas-Gulf & 32.6 & 2.3 & 7.0 \\
4 Great Lakes & 34.5 & 14.0 & 40.5 & 13 Rio Grande & 14.9 & 0.5 & 3.5 \\
5 Ohio & 45.1 & 19.4 & 43.0 & 14 Upper Colorado & 14.9 & 1.8 & 11.9 \\
6 Tennessee & 54.6 & 23.2 & 42.5 & 15 Lower Colorado & 12.7 & 0.4 & 3.5 \\
7 Upper Mississippi & 33.9 & 9.8 & 29.0 & 16 Great Basin & 12.3 & 2.0 & 16.6 \\
8 Lower Mississippi & 56.5 & 19.1 & 33.9 & 17 Pacific Northwest & 33.4 & 13.5 & 40.4 \\
9 Souris-Red-Rainy & 21.4 & 2.6 & 12.1 & 18 California & 24.0 & 10.5 & 43.6 \\
\hline
\end{tabular}

${ }^{a}$ Precipitation data was obtained from the PRISM Research Group, Oregon State University.

${ }^{\mathrm{b}}$ Runoff data was obtained from the U.S. Geological Survey (USGS) WaterWatch Program.

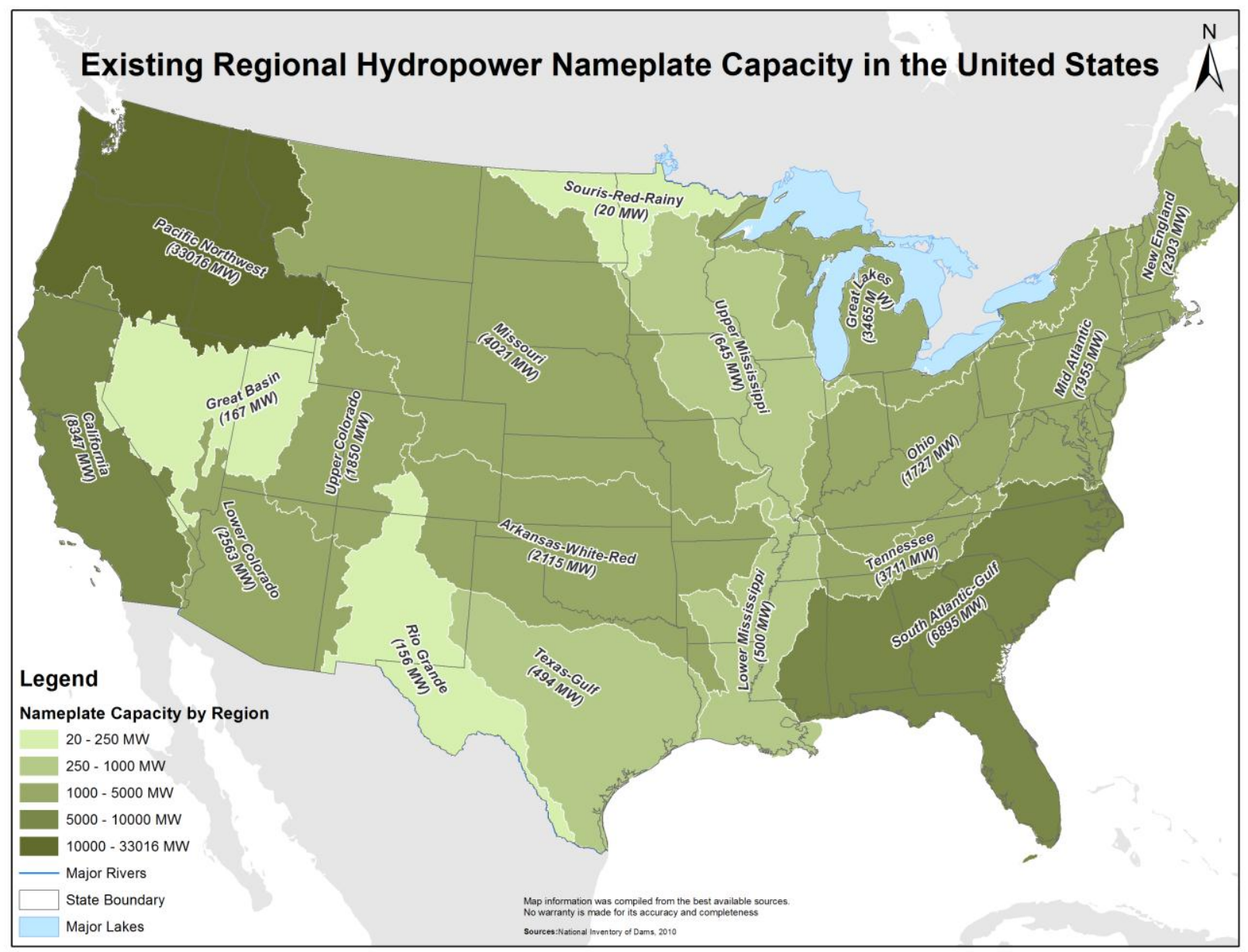

Figure 1. The existing hydropower capacity within each hydrologic region (Source: National Hydropower Asset Assessment Program Existing Hydropower Plant Summary, Hadjerioua et al., 2011)

For the Northeast and Great Lakes Regions (Regions 1, 2, and 4), both precipitation and runoff were abundant. The $\mathrm{Q} / \mathrm{P}$ ratios are high due to higher latitude, since cooler temperatures reduce evaporation and evapotranspiration. Due to the sufficient water resources, there has been extensive, mostly non- 
federal hydropower development in these regions. For the South Atlantic-Gulf Region (Region 3), the precipitation is among the highest, mostly due to hurricanes and summer convective storms. Although the high evaporation reduces the available runoff, there are still abundant water resources for hydropower generation. The high summer precipitation brings in challenges related to flood operation. The overall Mississippi River Basin (Regions 5-8, 10, and 11) covers nearly half of the U.S. territory. The eastern areas - the Ohio and Tennessee Regions (Regions 5 and 6) - are the wettest with low evaporation. These two regions have been historically important for hydropower generation, and they are still good potentials for future development. The western parts of the Mississippi River Basin (Regions 10 and 11) are much drier, and the greater evaporation causes large losses in effective precipitation. Other competing, consumptive water uses (e.g., municipal and irrigation) become important and may restrict the water availability for hydropower generation. The huge watershed area of the Mississippi River system results in high magnitude of streamflow downstream (Regions 7 and 8). To assist the river transportation, a series of locks and dams were built by the United States Army Corps of Engineers (USACE) to control the river stage. Many of these dams have not been utilized for hydropower generation, and-it will be shown later - they have the highest potential for NPD development.

The Souris-Red-Rainy Region (Region 9) is the upstream portion of river systems that drain north into Canada. Due to lower populations and available water resources, hydropower has not been a focus in this region. The Texas-Gulf and Rio Grande Regions (Regions 12 and 13) are among the driest in the United States. Although most of the NPDs are located in the State of Texas, the future hydropower potential is, in fact, limited by available precipitation and low Q/P ratios. The Colorado River system (Regions 14 and 15) also has relatively low precipitation and runoff. The regional water supply heavily relies on storage in large reservoirs, such as Glen Canyon Dam and Hoover Dam. Although not the main focus, these huge water storage projects permit high hydropower generation in these regions. The Great Basin (Region 16) is a closed watershed with limited water resources; there are comparatively fewer existing hydropower projects in this region. The Pacific Northwest (Region 17) is the most important region for U.S. hydropower generation. Both precipitation and runoff are abundant, and evaporation losses are low. The largest U.S. hydropower plant, Grand Coulee, is located in this region along with several other large projects (e.g., Chief Joseph). California (Region 18) is also an important hydropower provider; the numerous Central Valley projects in California create a large capacity for hydropower generation. One special feature of California is that flow diversion was utilized in several projects, resulting in high hydraulic head for hydropower generation. Although both the Pacific Northwest and California already provide large amounts of hydropower, the environmental concerns, such as fish habitat, may pose challenges for future development. Because the western United States (Regions 10-18) is much drier overall than the eastern regions, hydropower generation needs to be coordinated with other competing water usage. The DOI's Bureau of Reclamation (Reclamation) is assigned the responsibility of water management and supply in the western United States.

\section{Methodology}

\subsection{Energy Production Models for a Non-Powered Dam}

Consistent with previous studies (DOI et al., 2007; Reclamation, 2011), the following formula was utilized to estimate the potential hydropower generation at NPD sites: 
Potential Hydropower Generation (in megawatt hours or MWh) $=\mathrm{Q} * \Delta \mathrm{H}^{*} \eta^{*} \mathrm{~T} / 11800$ (1)

In Equation (1), $\Delta \mathrm{H}(\mathrm{ft}$ ) is the gross head for hydropower generation, $\eta$ is the generating efficiency (currently assumed to be 0.85 in this assessment), and $\mathrm{Q}\left(\mathrm{ft}^{3} / \mathrm{s}\right)$ is the average flow during the total generation period $\mathrm{T}$ (hour). While Equation (1) provides a straightforward way to estimate the power potential, there remain true challenges regarding how to estimate the parameters for a large number of NPDs given the available data. Ideally, the flow-duration curve based on at least 10 years of record needs to be developed at each NPD site so that wet, dry, and normal hydrological years can be captured. However, such a task is challenging at the national scale since most of the NPDs are located on ungauged streams or have limited historical observation. Therefore, in this assessment $\mathrm{Q}$ cannot be estimated by the commonly used 30\% exceedance level from daily flow-duration curves (criterion used in Reclamation, 2011). Estimating the gross head $-\Delta \mathrm{H}-$ available at the NPD with accuracy also is challenging. It is not possible, within the present effort, to obtain and analyze a daily headwater and tailwater elevation time series for each NPD. Thus, the potential energy must be estimated from available statistics for each site. For a national-level analysis, reasonable alternatives must be sought.

In this assessment, monthly hydropower generation was computed using a constant gross head derived from the NID and other methods (see head adjustment, Chapter 2.4) and the estimated monthly mean flow at each NPD site assuming that all flow can be utilized for hydropower generation. By summing the hydropower generation for each month, the potential annual generation can be estimated; this represents the maximum theoretical hydropower generation one may obtain at an NPD site. A regional capacity factor $\left(C_{f}\right)$, which was computed from existing hydropower plants (Hadjerioua et al., 2011), was then utilized to estimate the potential capacity.

- Capacity Factor Definition: The ratio of the actual energy produced in a given period, to the hypothetical maximum possible - i.e., running full-time at rated power.

- Regional Computed Capacity Factor: Capacity factor for this study was computed based on 8-year (2001-2008) recorded Energy Information Administration (EIA) generation for all hydropower plants in the United States; a regional capacity factor then was developed and assigned to compute the potential site installed capacity.

- Capacity Factor Limitations: Since the actual hydropower production is mainly a function of hydrology, operational constraints, demand, and dam type (tributary, main stem, run of river, etc.), there will be some overestimation or underestimation in the computed installed capacity when using an overall regional historical capacity factor. It is expected that appropriate site-specific capacity factors could be determined after a detailed feasibility study addressing all site characteristics (hydrology, hydraulic, environment, demand, machinery, etc.).

The capacity factor was computed by:

Capacity Factor $\left(\mathrm{C}_{\mathrm{f}}\right)=$ Annual Generation / (Installed Capacity $\left.* 365 * 24\right)$ 
In Equation (2), the actual historical generation was observed at existing hydropower plants (collected from EIA, 2010). If all generating units in a hydropower plant run continuously year-long, the actual generation will be close to the installed capacity multiplied by the entire hours in one year; hence, the capacity factor will be close to one. However, because streamflow fluctuates significantly over time, actual capacity factors are significantly less than one. The $\mathrm{C}_{\mathrm{f}}$ computed from existing plants provides one way to estimate the installed capacity from Equation (1). The following energy production model is therefore utilized in this assessment:

$$
\text { Potential Capacity }(\mathrm{MW})=\text { Potential Power Generation }(\mathrm{MWh}) /\left(\mathrm{C}_{\mathrm{f}} * 365 * 24\right)
$$

By using the above equations jointly, the potential hydropower generation and capacity are estimated at each NPD site. However, this capacity value assumes construction of a powerhouse that can pass all available water for the site for the generation of electricity; designed and developed powerhouses subject to economic limitations on size will be significantly smaller in capacity.

Several national-scale datasets (listed in Figure 2) were utilized for the assessment, and each component is discussed in the following subsections. For the reasons discussed in Section 1, the assessment aims to provide regionally comparable estimates of maximum NPD potentials for the entire United States for the purpose of policy considerations. The results may be used to identify potential regions and set priorities instead of getting a precise estimate at a specific site. Identification of the most appropriate sites and designs for investment will still rely on developers' efforts.

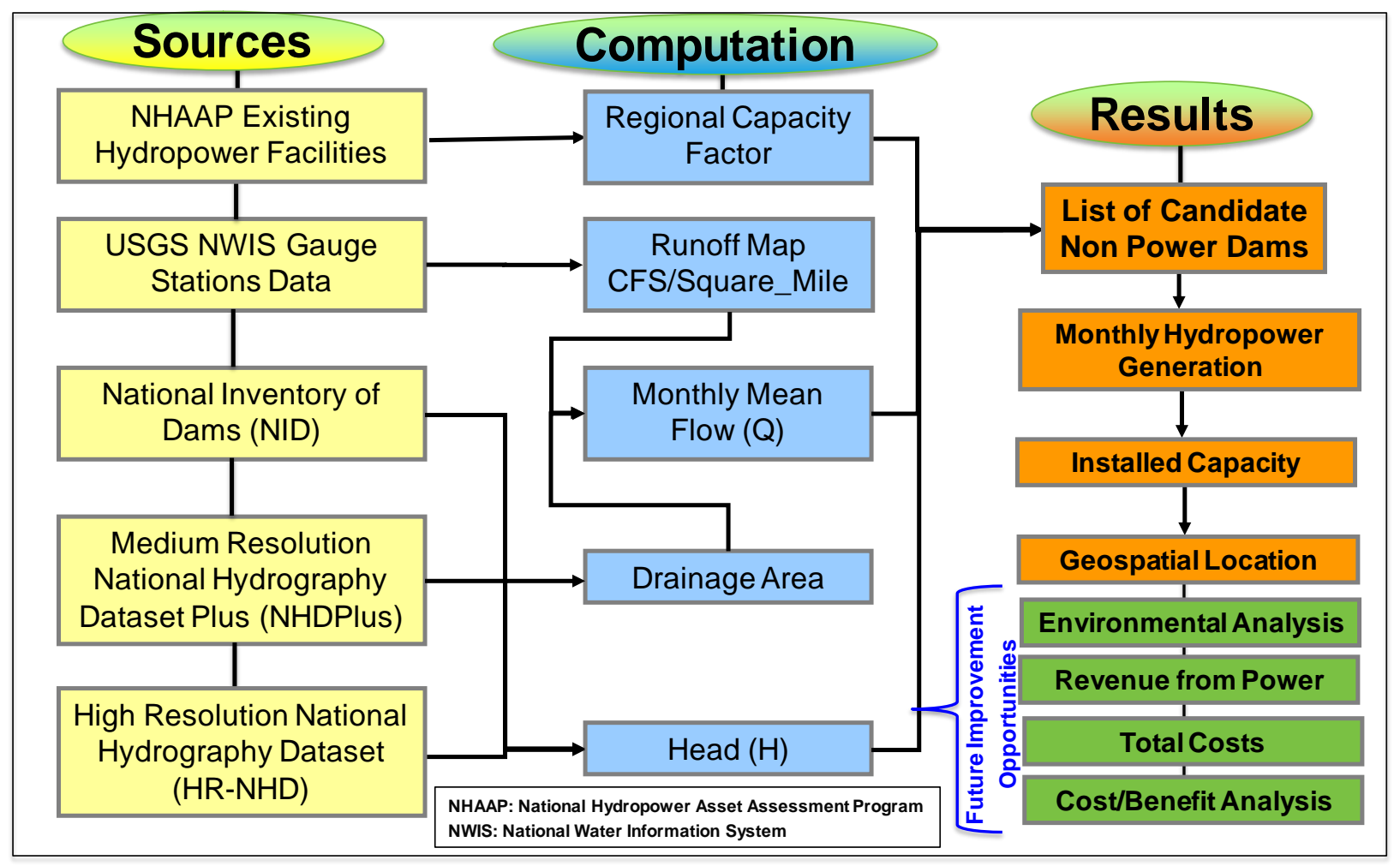

Figure 2. Approach to the NPD resource assessment 


\subsection{Data Requirements and Sources for Nationwide Assessment of NPD Potential}

As noted above, in order to estimate potential hydropower capacity for NPDs using the electricity generation model, several types of information are needed: monthly flow, head, and monthly capacity factor. Most of the information is not readily available. A wide variety of data sources were utilized to assemble the information needed for the energy generation model.

\subsubsection{USACE NID}

NID was utilized in this assessment to provide a comprehensive list of the NPDs and their corresponding dam heights. The goal of NID is to include all dams in the United States that meet at least one of the following criteria:

1) High hazard classification - loss of one human life is likely if the dam fails.

2) Significant hazard classification - possible loss of human life and likely significant property or environmental destruction if the dam fails.

3) Equals or exceeds 25 feet in height and exceeds 15 acre-feet in storage.

4) Equals or exceeds 6 feet in height and exceeds 50 acre-feet in storage.

Congress first authorized the USACE to inventory dams in the United States with the National Dam Inspection Act (Public Law 92-367) of 1972. The NID was first published in 1975, with a few updatesas resources permitted - over the next 10 years. The Water Resources Development Act of 1986 (P.L. 99-662) authorized USACE to maintain and periodically publish an updated NID, with re-authorization and a dedicated funding source provided under the Water Resources Development Act of 1996 (P.L. 1043). USACE also began close collaboration with the Federal Emergency Management Agency (FEMA) and state regulatory offices to obtain more accurate and complete information. The National Dam Safety and Security Act of 2002 (P.L. 107-310) reauthorized the National Dam Safety Program and included the maintenance and update of the NID by USACE. The most recent Dam Safety Act of 2006 reauthorized the maintenance and update of the NID. The latest version of NID, 2007

(http://www.nid.usace.army.mil), contains data about 83,987 dams together with such information as their purpose, location, river name, drainage area, dam height, dam storage, ownership, and primary usage. Although the NID contains most of the dams in the United States, other NPDs that are missing in the database are included in this assessment when identified from the databases described below.

\subsubsection{Dams from Reclamation}

Data for about 450 dams, along with their characteristics, were collected from Reclamation. Among those dams were more than 100 that were not included in the NID. These dams are merged with NID as a full list of dams for NPD resource assessment.

\subsubsection{National Hydropower Asset Assessment Program (NHAAP) Baseline Database}

The NHAAP (Hadjerioua et al., 2011) describes the development and construction of the baseline engineering and geospatial information systems and integrated data sets that characterize the hydropower generation inventory in the United States. The NHAAP baseline database is designed to assess and 
analyze the existing national hydropower infrastructure and provide historical data to study and plan for future potential hydropower upgrades, as well as potential increases in the U.S. hydropower generation.

\subsubsection{Natural Resources Conservation Service Watershed Boundary Dataset (WBD)}

Watershed boundaries define the aerial extent of surface water drainage to a point. The intent of defining hydrologic units (HU) for the WBD is to establish a drainage boundary framework, accounting for all land and surface areas. The latest version of the WBD defines six HU levels: region (HUC02), subregion (HUC04), basin (HUC06), sub-basin (HUC08), watershed (HUC10), and subwatershed (HUC12). Only regions (HUC02) were used in this report's nationwide assessment.

\subsubsection{USGS NHD}

The NHD is a comprehensive set of digital spatial data representing the surface water of the United States using common features, such as lakes, ponds, streams, rivers, canals, and oceans. High-resolution (1:24,000-scale) NHDs, covering the entire conterminous United States, were used in the NPD resource assessment (Simley et al., 2009).

\subsubsection{NHDPlus Version 1 from USGS and Horizon Systems Corporation}

By integrating a variety of datasets - including the National Elevation Dataset (NED), the National Land Cover Dataset (NLCD), and the WBD — into the medium-resolution (1:100,000-scale) NHD, NHDPlus Version 1 adds a variety of useful attributes to NHD features. These attributes include cumulative drainage area characteristics, flow direction, flowline minimum/maximum elevations and slopes, and flow volume and velocity estimates for each flowline in the stream network. (http://www.horizonsystems.com/nhdplus/)

\subsubsection{National Water Information System (NWIS) Gauge Observation from USGS}

Data were collected from about 22,000 USGS NWIS gauge stations, including location, drainage area, and monthly streamflow observations over the past 30 years. Among those 22,000 stations, 5,595 provide continuous streamflow observations from 1999 to 2008.

\subsection{Data Synthesis and Computation of Potential}

\subsubsection{Initial Dam Selection}

The initial selection process identifies dams that are candidates for hydropower development. Existing hydropower impoundments and dams that impound water released through existing powerhouses elsewhere on an impoundment are excluded from this set. Also excluded are dams with erroneous coordinates that could not be resolved through independent investigation of maps and records, as well as dams with erroneous flow or drainage area attributes that could not be corrected though independent investigation. Finally, dams with a reported height of less than five feet were excluded.

\subsubsection{Update NID Dams Location Using NHD}

In order to estimate the NPD flow correctly, a precise dam location is required. However, it was observed that some NID coordinates were not sufficiently accurate and, hence, a correct linkage between NPD and 
stream segment could not be built. The problem was partially resolved by using high-resolution NHD. High-resolution NHD provides adjusted locations of 41,757 NID dams. In such cases, the dam location is adjusted to be on the high-resolution NHD flowline. After updating NID dam locations, 697 dams were identified as having invalid locations and 267 dams were outside of the conterminous United States, thus they were deleted from the analysis.

\subsubsection{Exclude Existing Powered Dams, Auxiliary Dams, and Low Head Dams}

Based on the NID attributes, existing powered dams, auxiliary dams, and low head dams were excluded.

1) Criteria for selecting existing powered dams from NID: When the "Purpose" field in NID contains "H," which means hydroelectric, the dams are considered existing powered dams. There are 2,569 NID dams identified as existing powered dams. However, it was observed that this NID attribute was not always accurate and up-to-date. The NHAAP database was utilized in the quality control process (Section 2.4) to resolve this issue.

2) Criteria for selecting auxiliary dams from NID: When the "OtherStructureID" field in NID contains some value (i.e., not null), the dams are considered auxiliary dams. Since they share the same headwater with the main dam, it would be an overestimation to include their potential in the full national portfolio. There are 703 NID dams identified as auxiliary dams.

3) Criteria for selecting low head dams from NID: When the "NID_Height" field in NID is missing or less than 5 feet, the dams are considered low head dams. There are 319 NID dams identified as low head dams.

It also should be noted that some dams may fit into multiple criteria. For instance, some auxiliary dams may have an " $H$ " remark in the "Purpose" field. The NPDs that remained in the database after filtering through the three criteria are analyzed further to address these cases.

\subsubsection{Identification of Dams on Streams with Negligible Streamflow}

The spatial analysis process of dam context was performed using NHDPlus (1:100,000 scale) and highresolution NHD (1:24,000 scale) to ensure accurate registration of dams to stream segments. The highresolution NHD analysis is essential for correct registration of dams with negligible streamflow (DWNS) that impound very small streams. These streams do not appear in the medium resolution NHDPlus, so exclusive use of NHDPlus to register streams would erroneously assign DWNS to larger streams and overestimate their production potential. 
The criteria for identifying DWNS, as long as any one is met, are as follows:

1) A dam is close to a high-resolution NHD flowline, but far from a lower-resolution NHDPlus flowline (Figure 3).

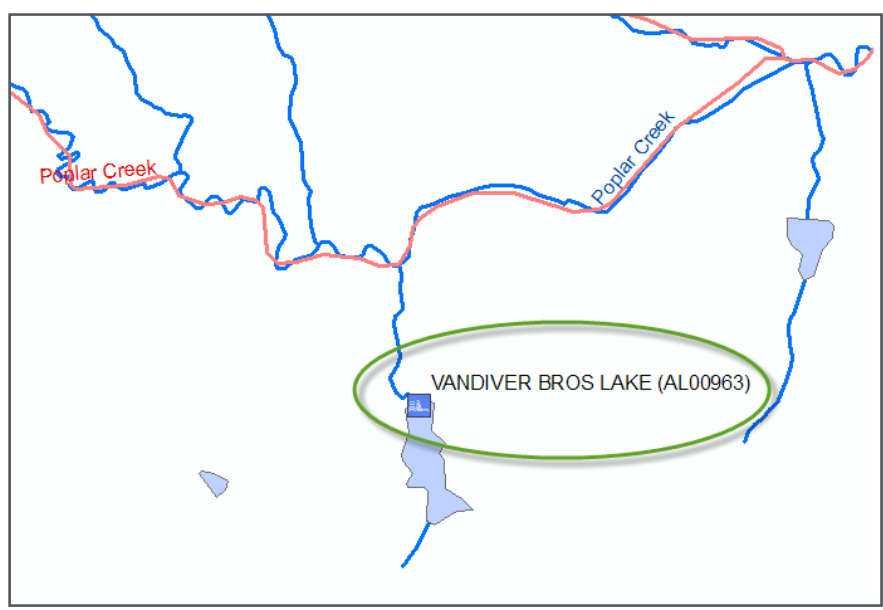

NHD Flowline (High Resolution)

NHDPlus Flowline (Medium Resolution)

NID Dam

Figure 3. Illustration of the first criterion classification of DWNS - In this example, because the dam "Vandiver Bros Lake" is close to NHD flowline but far from NHDPlus flowline, it is designated as located on segment with negligible streamflow.

2) A dam is not close to either a high-resolution NHD flowline or an NHDPlus flowline (Figure 4).

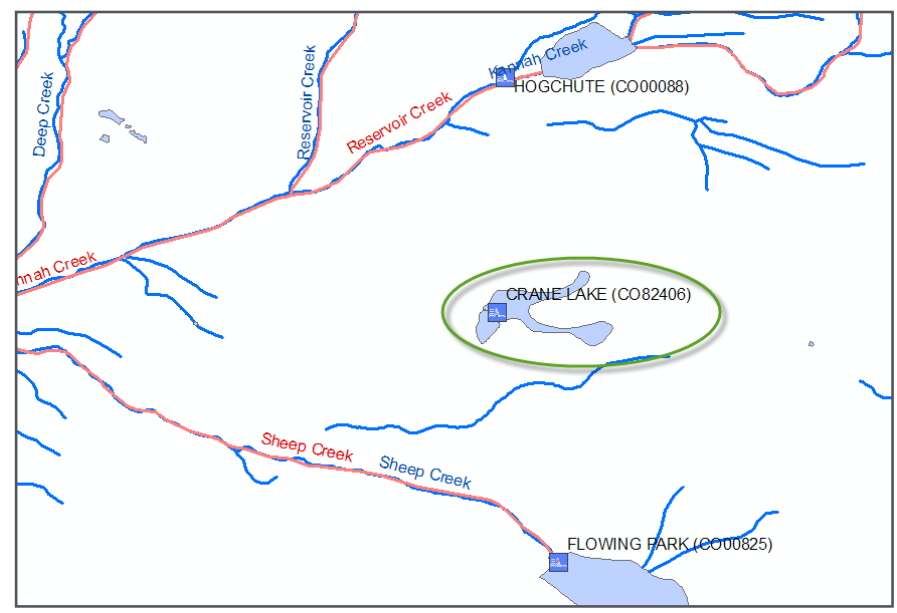

NHD Flowline (High Resolution)

NHDPlus Flowline (Medium Resolution)

NID Dam

Figure 4. Illustration of the second criterion for selecting DWNS - In this example, because the dam "Crane Lake" is not close to any NHD flowline or NHDPlus flowline, it cannot be linked to any stream and is designated as located on segment with negligible streamflow.

There are 24,478 NID dams classified as DWNS. Although there may be some hydropower potential for these types of NPDs, given that there is very limited flow information to support the computation of their potential, they cannot be correctly estimated based on the current data availability. These 24,478 dams could be further analyzed in future small hydropower research efforts to estimate their aggregate potential, though this could be negligible. The remaining 55,707 NPDs can be estimated for their hydropower potential in the following steps. 


\subsubsection{Streamflow}

Although the most credible approach to estimate available streamflow for hydropower generation is through stream gauge monitoring, many NPDs are not monitored or have streamflow records for a duration of less than 10 years. Some preliminary estimates are available at the national scale, such as the annual mean flow provided in NHDPlus; however, seasonal variability, which is crucial to hydropower production, is usually unavailable. Therefore, alternatives must be sought, especially given the large number of NPDs included in this assessment.

The monthly mean flow was estimated at each of the NPD sites by relying on several available data sources. The key concept of estimating monthly mean streamflow is based on the following equation:

$$
\text { Streamflow }=\text { Drainage Area } * \text { Runoff }
$$

In Equation (4), "Drainage Area" is the cumulative drainage area (square miles) of the basin above an NPD. "Runoff" is the monthly mean normalized streamflow (cfs/square mile) within an NPD's entire drainage area. Given that the streamflow magnitude is strongly correlated to drainage area, a runoff map has been widely applied in practice to estimate flow at ungauged locations. The monthly runoff at the HUC06 level was estimated in this study to help identify the monthly variability of streamflow.

However, this over-simplification may also introduce some errors. A quality control procedure therefore is introduced (described in Section 2.4) to ensure the accuracy of the estimates.

\subsubsection{Drainage Area}

Two sources were utilized to estimate the drainage area for each NPD. The first source is NID. In NID, drainage area is provided for more than half of the dams, but the information sometimes is inaccurate. A better source of drainage area information is NHDPlus. For most of the flowlines (linear features, including stream/river, canal/ditch, pipeline, artificial path, coastline, and connector), NHDPlus provides the cumulative drainage area at the endpoint (outlet) of the flowline. The average length of flowlines in NHDPlus is about 1.2 miles. So, the drainage area of an NPD is approximately identical to the cumulative drainage area of the flowline on which the dam is located. Spatial analyses were performed using NID and NHDPlus stream network to find the flowline on which an NPD is located. Then, the corresponding drainage area provided in NHDPlus was used. This process is described in Figure 5. 


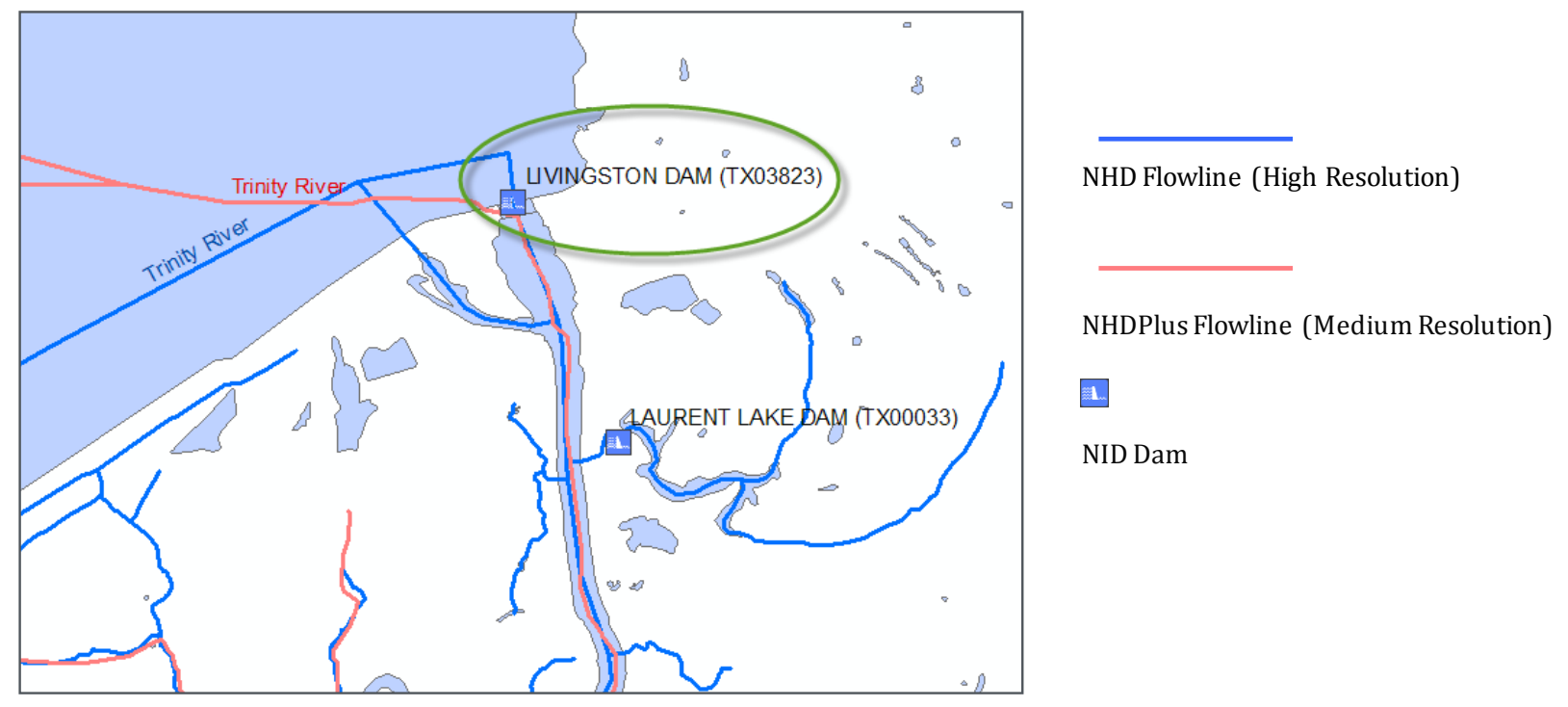

Figure 5. Illustration of linkage between NID and NHDPlus - In NID, Livingston Dam is linked to an NHDPlus flowline (in red color), which represents the Trinity River. The accumulative drainage area for this NHDPlus flowline is 16,572 square miles, which will be used as the dam's drainage area.

\subsubsection{Runoff}

The monthly mean runoff was calculated for all basins (HUC06) based on observation data from 5,595 USGS NWIS gauge stations with continuous streamflow observations between 1999 and 2008. The calculation is an area-weighted average method based on the streamflow observation, location, and drainage area of these 5,595 selected gauge stations. Within each HUC06, the mean runoff for each calendar month is computed from all stations located in that basin. The annual runoff is shown as an example in Figure 6. As shown, most of the surface water runoff is located in the eastern and northwestern United States.

\subsubsection{Streamflow Calculation and Selection}

For each NPD, the basin runoff and drainage area are applied in Equation (4) to estimate the monthly streamflow. Because there were two versions of drainage area, alternative estimates of streamflow were computed from the NHDPlus and NID. The selection of streamflow was based on this criterion: use the streamflow based on drainage area from NHDPlus unless it is at least 50 times greater than the streamflow based on drainage area from NID. The criterion was needed because, owing to inaccuracy of dam locations, the spatial analysis process might mistakenly find the wrong NHDPlus flowline on which that dam is located, which will significantly affect the accuracy of the drainage area retrieved from NHDPlus. As mentioned earlier, an additional quality control step is introduced later to ensure the reasonableness of the flow estimates. Figure 7 shows the calculated monthly mean streamflow for John Sevier Dam, located in Tennessee, which was derived by this method. 


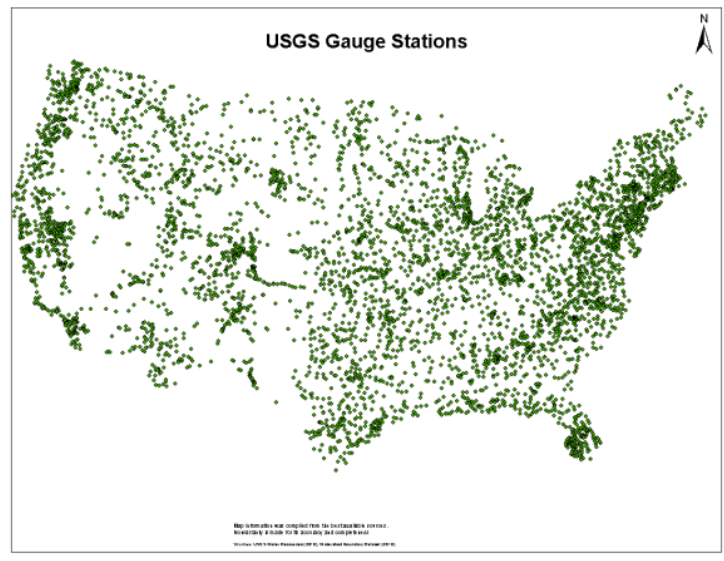

Observed flow for selected USGS gauge stations

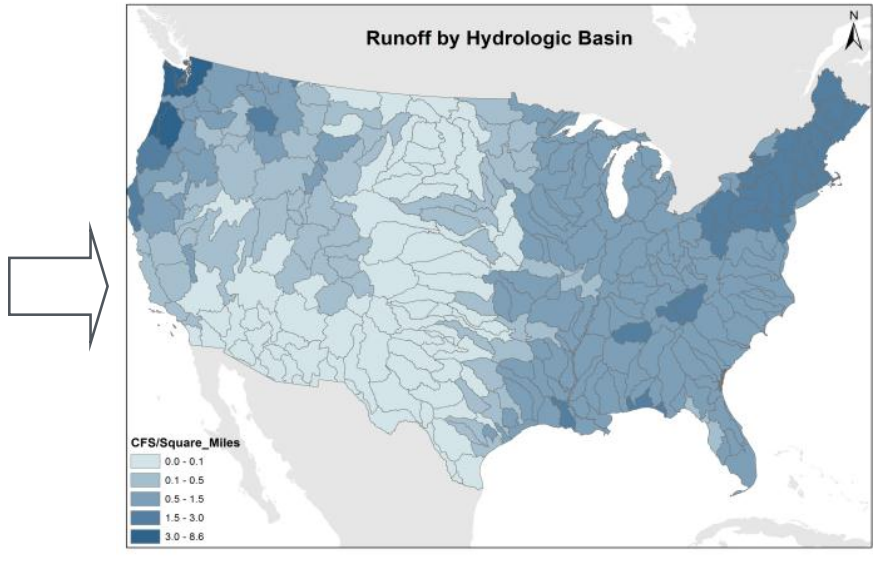

Runoff (CFS/Square_Miles)

Figure 6. Illustration of runoff derivation

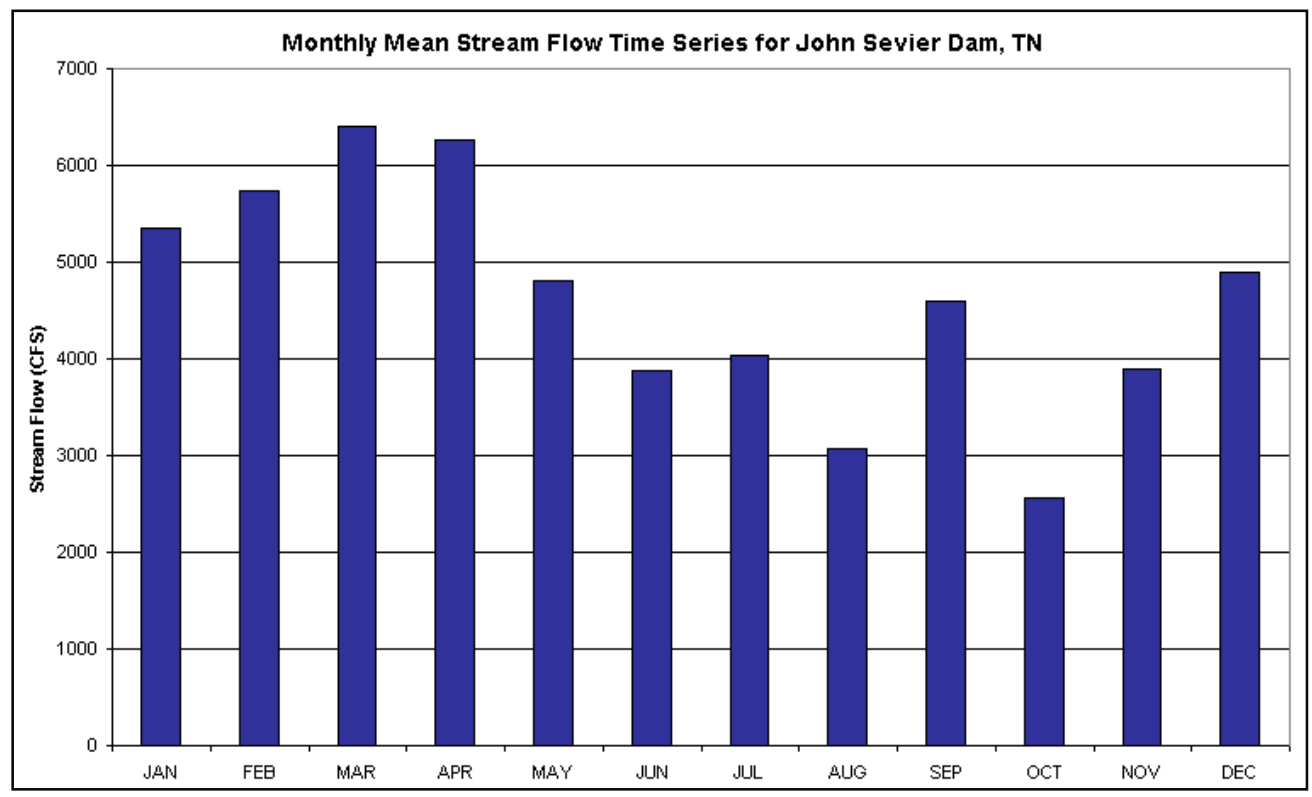

Figure 7. Monthly mean streamflow time series for John Sevier Dam, Tennessee

\subsubsection{Hydraulic Head}

Given the national scope of this study, the choices of penstock and pipeline-which are generally utilized to increase the hydraulic head for hydropower generation - were not considered. The focus is to identify NPD potential with the least new construction and, hence, only the head created by the current existing NPDs was considered. Although the most accurate estimate of hydraulic head is the height difference between headwater and tailwater elevations, such information is not commonly available in the databases. Therefore, the dam height information in NID was utilized as a surrogate to estimate hydraulic head. Four types of height information are provided in NID (graphically depicted in Figure 8), including the following: 
1) Hydraulic Height: Vertical difference between the maximum design water level and the lowest point in the original streambed.

2) Dam Height: Vertical distance between the lowest point on the crest of the dam and the lowest point in the original streambed.

3) Structural Height: Vertical distance from the lowest point of the excavated foundation to the top of the dam. Top of dam refers to the parapet wall and not the crest.

4) NID Height: Maximum value among Hydraulic Height, Dam Height, and Structural Height.

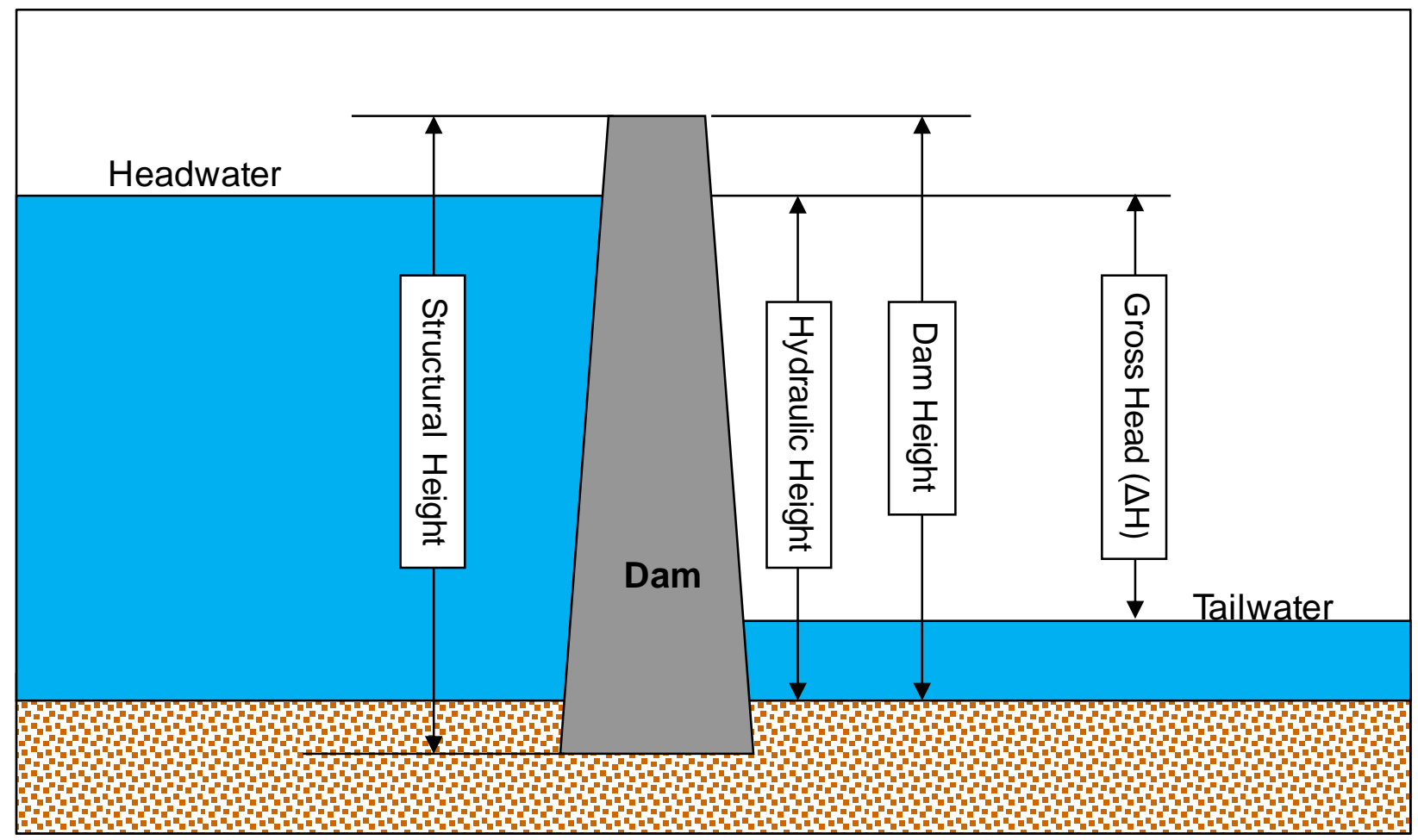

Figure 8. NID height definitions

Although it seems that the hydraulic height could be the best choice to represent the gross head, especially for sites with small tailwater depths, this information is not available for many NPDs. However, sometimes the hydraulic height given is equal to the dam height; in these instances, using the hydraulic height will grossly overestimate the computed potential power and, thus, the potential installed capacity. Therefore, as a "rule of thumb" estimate, $70 \%$ of the NID height is used. The following empirical rules estimate the gross head for the NPDs:

1) If Hydraulic Height is not provided, use $0.7 *$ NID Height.

2) If Hydraulic Height and NID Height are both provided and are equal, use $0.7 *$ NID Height.

3) If Hydraulic Height is provided but is greater than $0.7 *$ NID Height, use $0.7 *$ NID Height.

4) If Hydraulic Height is provided and is less than $0.7 *$ NID Height, use Hydraulic Height. 
In the case of major main-stem NPDs and high dams (over 100 feet), these assumptions were supplemented by analysis of data from navigation lock lift heights and from gauge stations to gain a more realistic estimate of gross head (the difference between headwater and tailwater elevations). For other dams, there could be some high uncertainties between the NID dam height-based estimate and the actual gross head available for power generation. The primary uncertainty in estimating energy potential, based on these NID dam height assumptions, is that the influence of tailwater elevation and the absence of accurate data on tailwater elevation were not included in the current data sources. In addition, the seasonal variability of hydraulic head is not available in most of the cases. The current choices served as preliminary estimates. The $70 \%$ (or 0.7 multiplier factor) used with the NID dam height is based on the assumption that about $70 \%$ of the NID dam height should be considered as gross head available for power. The tailwater depth and the distance from the upper pool to the dam crest are assumed to be about $30 \%$. This assumption is considered to be reasonable when the NID height is equal to dam height. When the NID height is equal to structural height, since there is an additional excavation depth to be included, the gross estimate head available for power could be overestimated; however, only $2 \%$ of the total number of NPDs with $0.4 \%$ of the total estimated potential installed capacity was computed using structural dam height in this study. The actual time-varying head at a specific site should be monitored as part of a feasibility study or characterized by detailed pool elevation records from the site operator. Summary for gross head estimation used in this study is shown in Table 2.

Table 2. Type of Heads Used to Estimate Potential Installed Capacity

\begin{tabular}{|l|r|r|}
\hline \multicolumn{1}{|c|}{ Estimated Gross Head } & Number of NPD & \multicolumn{2}{c|}{$\begin{array}{c}\text { Total Potential Capacity } \\
\text { (MW) }\end{array}$} \\
\hline Adjusted using Lock and Dam lift from USACE & 87 & $6,921.6$ \\
\hline Computed using $0.7^{*}$ Dam Height & 49859 & $3,744.2$ \\
\hline Adjusted during quality control (NPD > 100 feet) & 62 & 729.9 \\
\hline Using NID Hydraulic Height & 3,329 & 599.8 \\
\hline Using 0.7 * NID Structural Height & 1050 & 44.24 \\
\hline Adjusted from Reclamation Resource Assessment & 4 & 21.5 \\
\hline Total & $\mathbf{5 4 , 3 9 1}$ & $\mathbf{1 2 , 0 6 1 . 2}$ \\
\hline
\end{tabular}

\subsubsection{Capacity Factor}

The regional capacity factor was obtained from the NHAAP database. By using Equation (2), the capacity factor of each existing hydropower plant with available generation and capacity data from 2001 to 2008 was computed (see Figure 9). The plant generation is then utilized as a weighting factor to average the capacity factor for each of the hydrologic regions (HUC02). Therefore, the regional capacity factor represented the ratio of current generation to the maximum possible generation when generators are constantly operated. The capacity factor was utilized in Equation (3) to estimate the potential NPD capacity. 


\section{NHAAP Regional Generation-weighted Capacity \\ Factor, 2001-2008}

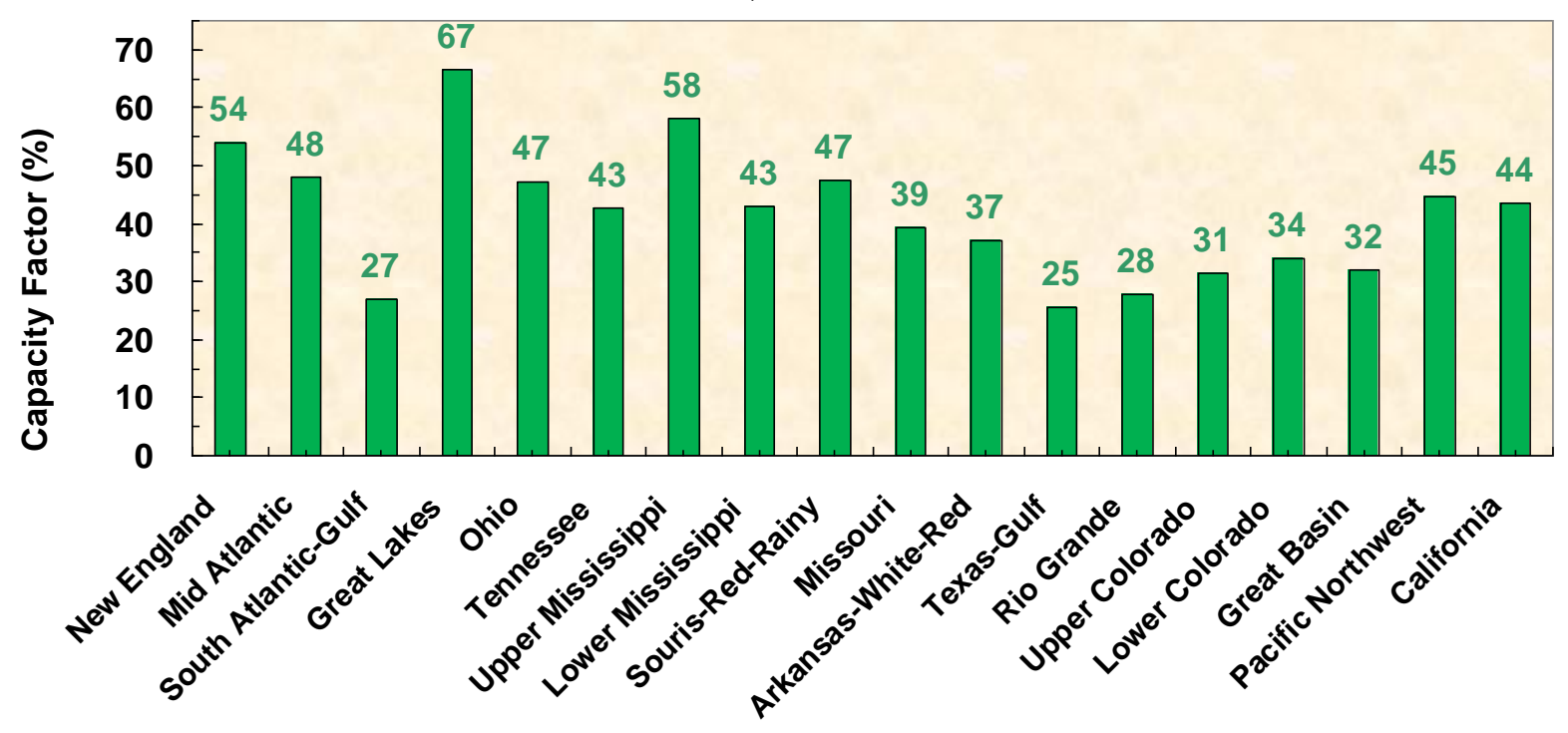

Figure 9. Computed regional capacity factors

\subsubsection{Potential Generation and Capacity}

With Equation (1), using hydraulic head and monthly mean streamflow, the mean monthly potential NPD generation was calculated. Mean annual potential NPD generation then can be derived by summing monthly estimates of generation together. The annual potential generation then is fed into Equation (3), along with the regional capacity factor, to estimate the potential capacity. A program was developed to automatically compute the power potential for all NPDs. The preliminary results then were examined through a quality control process.

\subsection{Quality Control}

Although most of the NID non-powered dams were linked to the NHDPlus stream segments through the algorithm described in Section 2.3, mismatches occasionally occurred. The mismatch typically resulted in unrealistically high flow, which then overestimated the power potential. These errors were usually caused by the following:

- Inaccurate coordinates and attributes of some NID dams

- Different regional hydrologic characteristics

- Inconsistent coordinates between NID and NHD

- Outdated information of some NID attributes

- Overestimated head (mostly for run-of-river dams). 
As a result, quality control through manual checking was used to ensure the accuracy of the national estimates. The major quality control steps include the following:

1) Removal of smaller ponds next to major rivers - It is a fundamental GIS limitation that the same geographical units may have slightly different coordinates across various datasets. One common solution is to assign a tolerance distance when merging different datasets together (in this case, NID and NHD). However, since many ponds are located near major rivers (e.g., Ohio River), there were many cases that these off-stream ponds were pushed into major rivers and resulted in overestimated power potential. The problem, which was most common in HUC Region 5 (Ohio), was resolved by examining satellite images.

2) Removal of existing hydropower plants - While information was provided in the NID to indicate whether or not a dam was utilized for hydropower generation, such information was not always accurate and up-to-date. The latest hydropower plant inventory was obtained from the NHAAP to correct errors in the NID database. In cases where an NPD shares the same headwater with an existing hydropower dam, the NPD was excluded during the quality control process.

3) Flow adjustment - Although two different methods were utilized to estimate the monthly flow in ungauged streams, the most accurate estimates are derived directly from nearby gauge stations. During the quality control, the annual mean flow provided by NHDPlus was utilized as a reference standard to help with validating the flow estimates. If the annual flow estimate was not within a $10 \%$ difference of the value in NHDPlus, flow adjustment was considered. In most cases, the monthly flow estimates were rescaled to match the annual mean flow from NHDPlus.

4) Head adjustment - Much of the NPD power potential comes from the USACE navigation system (locks and dams). Due to the need of inland river transportation, the flow discharge at locks and dams was always high and can be a potential source of future hydropower. However, the NID dam height may not be reasonably used as a proxy of head in these cases due to the high tailwater elevation. Therefore, the average lift information was obtained from USACE to replace the original head estimate. Although this quality control step resulted in a $7 \mathrm{GW}$ decrease of power potential, the locks and dams remain good candidates, even after the large reduction. In addition to locks and dams, head adjustment also was performed for those high head (>100 ft) and high potential (> $1 \mathrm{MW}$ ) NPD sites. The normal pool head water elevation (usually taken from the dam owner website or the operation documents) and tail water elevation (usually taken from the downstream USGS gauge stations) were identified as the maximum bounding range of the available head. Although this process is considered to be realistic, it is extremely time- and resource-consuming, and elevation measured from different sources may be determined inconsistently. This process resulted in another $0.5 \mathrm{GW}$ reduction of the power potential.

5) Removal of under-construction sites - It was noticed that some potentially developable sites already are under construction. For instance, several USACE locks and dams (e.g., Cannelton and Smithland) on the Ohio River are being developed for hydropower generation and, hence, were removed from the candidate list. Several other NPDs-including L\&D 52 and 53, Newburgh, and J.T. Myers - are expected to be replaced or converted for hydropower generation in the near future. The national NPD estimate will be adjusted periodically when new information becomes available. 
6) Updated from other regional resource assessments - Although flow and head can be estimated through the approach described in the previous section for a large number of NPDs nationwide, these estimates are only preliminary and will not be as accurate as the ones measured on-site. There have been many other regional efforts in evaluating potential hydropower sites in which the designed flow and head were determined based on the actual site conditions. Whenever a credible previous resource assessment becomes available, the information is utilized to improve the national NPD estimates in this study. Part of the Reclamation 2011 information was incorporated to provide more realistic estimate of head.

It should be noted that quality control is a time-consuming process and cannot be performed for all NPDs. Therefore, quality control checks commenced with the NPDs having the highest power estimates; these checks continued gradually following the descending order of power potential. At the current phase of this project, nearly 1,000 NPDs with high hydropower potential have been preliminarily checked.

Not all of the many NPDs analyzed have been subjected to detailed quality control checks for streamflow, head, energy, and capacity estimation. Quality control checking has focused on those dams with the greatest estimated energy production. The raw estimate from Section 2.3 revealed 54,801 NPD sites with potential capacities totaling $43.5 \mathrm{GW}$. The numbers were reduced to 54,561 NPDs with potential capacities totaling 19.7 GW after steps 1-3 (described in Section 2.4) were applied on part of the NPDs. The most recent estimate included steps 4-5 (described in Section 2.4); with the resulting potential capacity of $12 \mathrm{GW}$ was based on the remaining 54,391 NPDs. While many of these NPDs of lesser potential have not received explicit quality control review, such checks are unlikely to result in substantial increases or decreases in potential capacity because the NPDs with the highest power estimates already have been subjected to the quality control process.

\section{Results}

\subsection{Estimated Energy Availability}

Following the methodologies described in Section 2, the potential generation and capacity are estimated for more than 54,000 NPDs in the conterminous United States. These preliminary hydropower potentials consider only approximations of site characteristics (e.g., dam height) and hydrologic variability without further assessment of site feasibility, environmental impact, and economical benefit. At the current phase of assessment, the total potential capacity and annual generation are estimated to be, respectively, $12 \mathrm{GW}$ and 45 terawatt hours (TWh) per year-around 15\% of the existing U.S. conventional hydropower total. Current economic limitations on project size will likely produce designs with less capacity than indicated herein.

\subsubsection{Nationwide Potential}

Although a large number of NPDs are assessed in this study, most of the energy potential is found in a relatively small subset of dams. As illustrated in Figure10, the top 597 NPD sites, each with a potential capacity greater than $1 \mathrm{MW}$, contribute nearly $90 \%$ of the estimated additional national capacity from NPDs. In particular, $40 \%$ of the national total is from the top 25 NPD sites only. Therefore, quality control of the top NPD sites was important to ensure the reliability of the national estimate. It should be 
noted that all sites with potential capacity greater than $1 \mathrm{MW}$ have been examined during the quality control process.

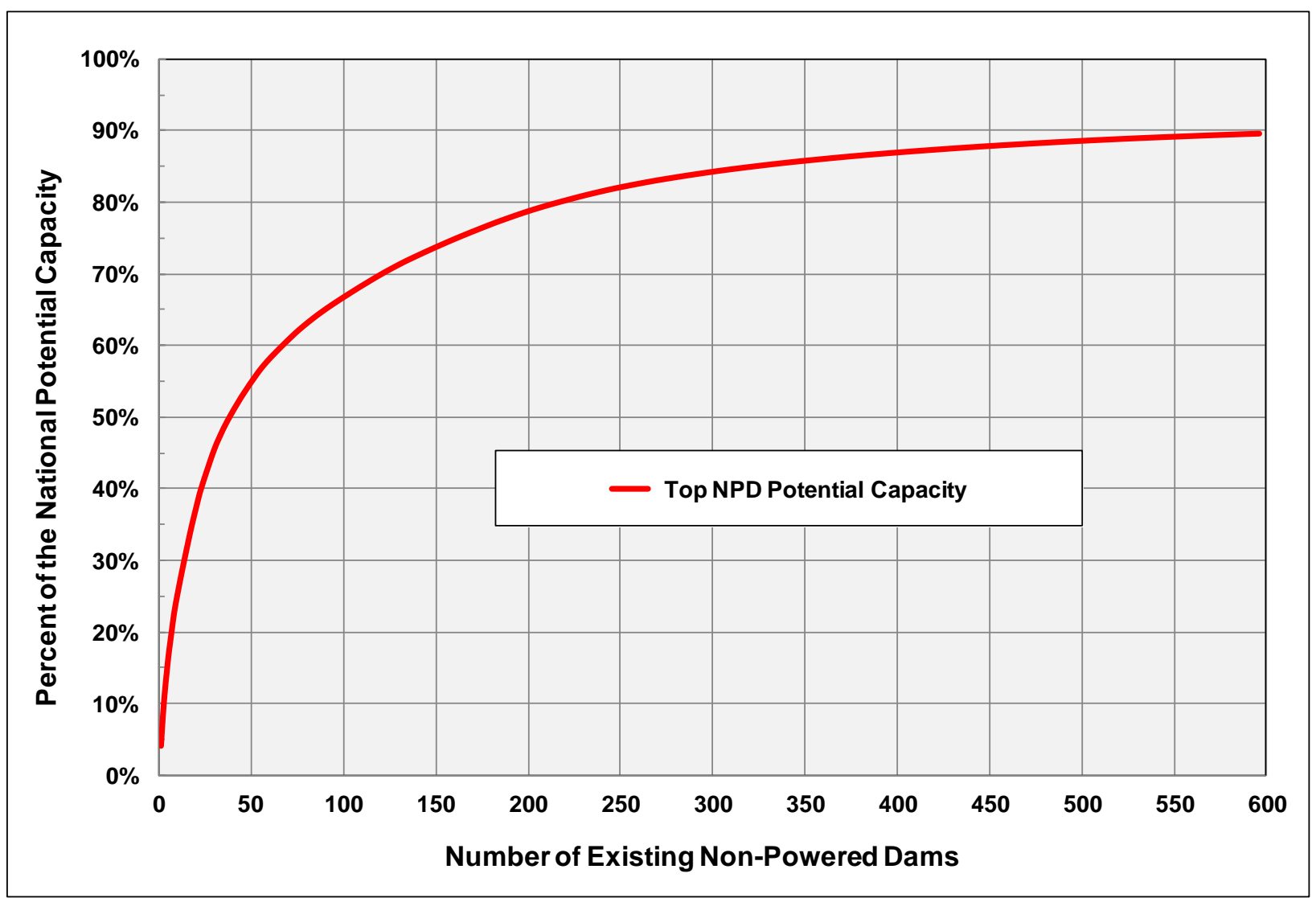

Figure 10. Cumulative potential capacity distribution of the top existing NPDs with the greatest potential added generation capacity

The top 597 NPDs have a potential capacity greater than 1 MW. A regional map of the NPD sites with potential capacity greater than $1 \mathrm{MW}$ is shown in Figure 11. Most of the potential sites are found in the northeastern United States, Ohio River Basin, and Upper and Lower Mississippi River Basins.

Specifically, high potentials are found for many USACE locks and dams - 87 sites with a total potential of $6.9 \mathrm{GW}$. The finding is reasonable because the streamflow magnitude must be sufficiently large at locks and dams to support river transportation. Because locks and dams were built mainly for navigation purposes instead of municipal water supply and irrigation, there may be less concern about impacts regarding other competing water usage. 


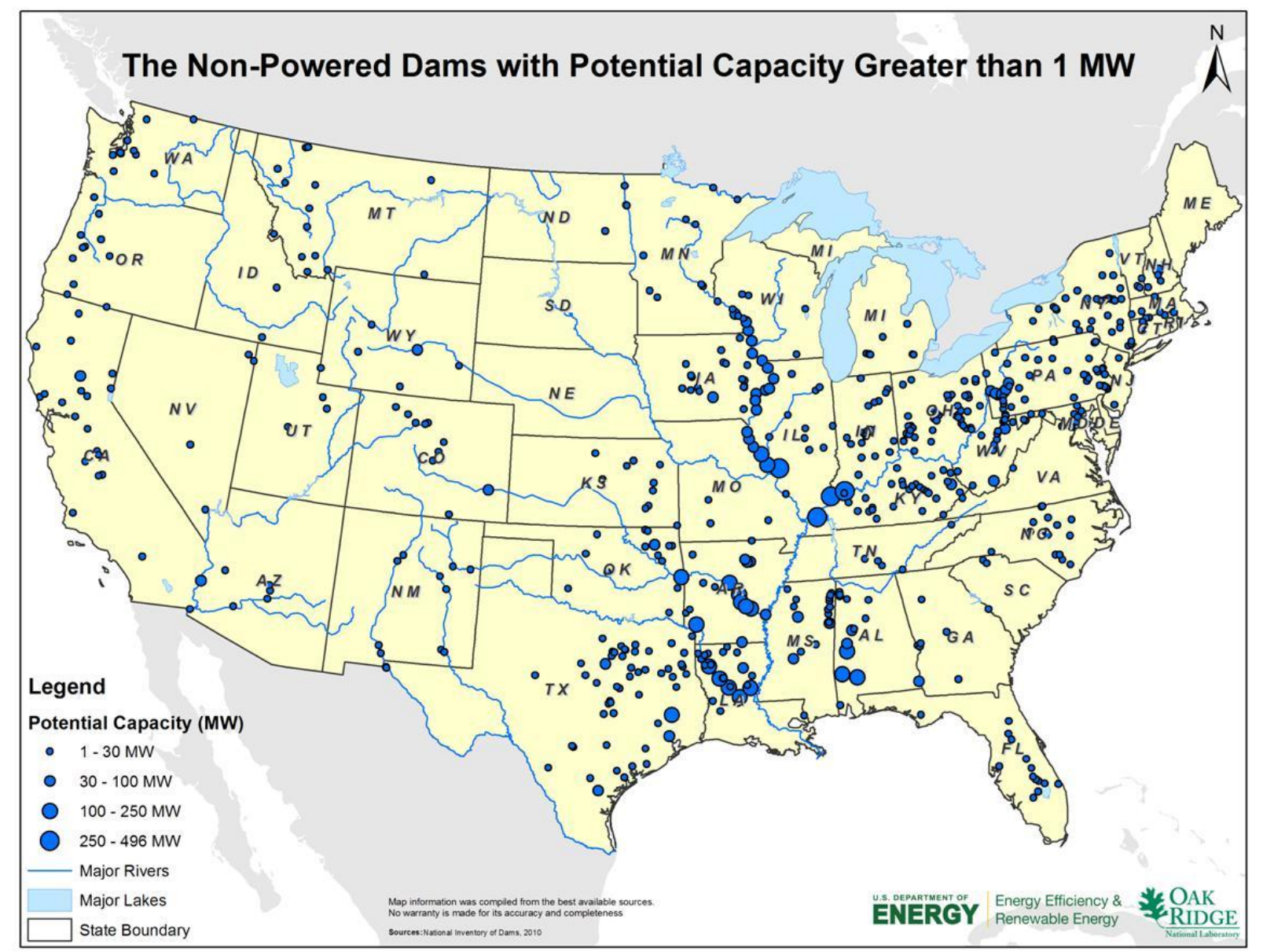

Figure 11. Location of the top NPDs with potential capacities greater than $1 \mathrm{MW}$

\subsubsection{Regional Potential by River Basin and State}

The NPD assessment is summarized in Table 3 by hydrologic regions. The top three regions are highlighted; namely Ohio, Upper Mississippi, and Arkansas-White-Red. As mentioned earlier, most of the hydropower potential identified within these three regions is located at navigation locks and dams located on relatively big rivers. The other summary is shown by state in Table 4. If a NPD was located on the boarder of multiple states, the potential capacity was distributed evenly into each neighboring state to compute the state total. According to this analysis, the greatest amount of hydropower potential is found in Alabama, Arkansas, Illinois, Kentucky, Pennsylvania, Texas, and Louisiana; this mainly is due to a series of Ohio River locks and high river flows. Many of these Ohio River locks are within the top 10 list of the potential NPD sites. It should be noted that other Ohio River locks and dams are not reflected in Table 3 and Table 4, including Cannelton, Smithland, and Meldahl, which were found to be suitable for hydropower development in the initial assessment. They were excluded during the quality control process because construction currently is underway to convert these NPDs for hydropower generation. 
Table 3. Summary of NPD Assessment by Hydrologic Regions Totaling 12 GW of Potential

\begin{tabular}{lll|lll}
\hline $\begin{array}{l}\text { Hydrologic Regions } \\
\text { (HUC02) }\end{array}$ & $\begin{array}{l}\text { Potential } \\
\text { Capacity } \\
(\mathrm{MW})\end{array}$ & $\begin{array}{l}\text { Potential } \\
\text { Generation } \\
(\mathrm{TWh} / \mathrm{yr})\end{array}$ & $\begin{array}{l}\text { Hydrologic Regions } \\
\text { (HUC02) }\end{array}$ & $\begin{array}{l}\text { Potential } \\
\text { Capacity } \\
(\mathrm{MW})\end{array}$ & $\begin{array}{l}\text { Potential } \\
\text { Generation } \\
(\mathrm{MWh} / \mathrm{yr})\end{array}$ \\
\hline 1 New England & 243 & 1.110 & 10 Missouri & 258 & 0.865 \\
2 Mid-Atlantic & 479 & 1.997 & 11 Arkansas-White-Red & 1898 & 5.960 \\
3 South Atlantic-Gulf & 1618 & 3.778 & 12 Texas-Gulf & 608 & 1.308 \\
\hline 4 Great Lakes & 156 & 0.903 & 13 Rio Grande & 98 & 0.241 \\
5 Ohio & 3236 & 13.603 & 14 Upper Colorado & 53 & 0.145 \\
6 Tennessee & 53 & 0.197 & 15 Lower Colorado & 124 & 0.370 \\
\hline 7 Upper Mississippi & 2027 & 9.943 & 16 Great Basin & 29 & 0.080 \\
8 Lower Mississippi & 743 & 2.802 & 17 Pacific Northwest & 225 & 0.871 \\
9 Souris-Red-Rainy & 58 & 0.239 & 18 California & 156 & 0.586 \\
\hline
\end{tabular}

Table 4. Summary of NPD Assessment by State Totaling 12 GW of Potential

\begin{tabular}{|lc|lc|lc|}
\hline State & $\begin{array}{c}\text { Potential } \\
\text { Capacity (MW) }\end{array}$ & State & $\begin{array}{c}\text { Potential } \\
\text { Capacity (MW) }\end{array}$ & State & $\begin{array}{c}\text { Potential } \\
\text { Capacity (MW) }\end{array}$ \\
\hline AL & 922 & ME & 19 & OH & 288 \\
AZ & 80 & MD & 48 & OK & 339 \\
AR & 1136 & MA & 67 & OR & 116 \\
CA & 195 & MI & 48 & PA & 679 \\
\hline CO & 172 & MN & 186 & RI & 13 \\
CT & 68 & MS & 271 & SC & 38 \\
DE & 3 & MO & 489 & SD & 12 \\
FL & 173 & MT & 88 & TN & 40 \\
\hline GA & 144 & NE & 7 & TX & 658 \\
ID & 12 & NV & 16 & UT & 40 \\
IL & 1269 & NH & 63 & VT & 17 \\
IN & 454 & NJ & 33 & VA & 50 \\
\hline IA & 427 & NM & 103 & WA & 85 \\
KS & 92 & NY & 295 & WV & 210 \\
KY & 1253 & NC & 167 & WI & 245 \\
LA & 857 & ND & 31 & WY & 45 \\
\hline
\end{tabular}

\subsection{Integration with Existing Hydropower Inventory and Other Renewable Energy Facilities}

Figure 12 illustrates the generation potential listed in Table 3. It is interesting to note that while hydropower is already a significant source of electricity in the Pacific Northwest and California regions, the best potential for new development at NPDs is at locations with less existing hydropower usage; in particular, there was major potential found in the Ohio, Upper and Lower Mississippi, and ArkansasWhite-Red regions. Therefore, new NPD development can help diversify the spatial distribution of national hydropower investment. More importantly, hydropower is found to be a complementary energy source with other renewables. A comparison is shown in Figure 13. 13. By overlaying the potential 
NPD sites with National Renewable Energy Laboratory (NREL) estimates of wind and solar power potentials (NREL, 2011), it can be seen how the development of hydropower at NPDs may complement the development of other renewable technologies and augment the national portfolio. While more wind and solar power potentials are found in the western and southwestern United States, hydropower development through NPDs can provide clean renewables for other regions in the nation.

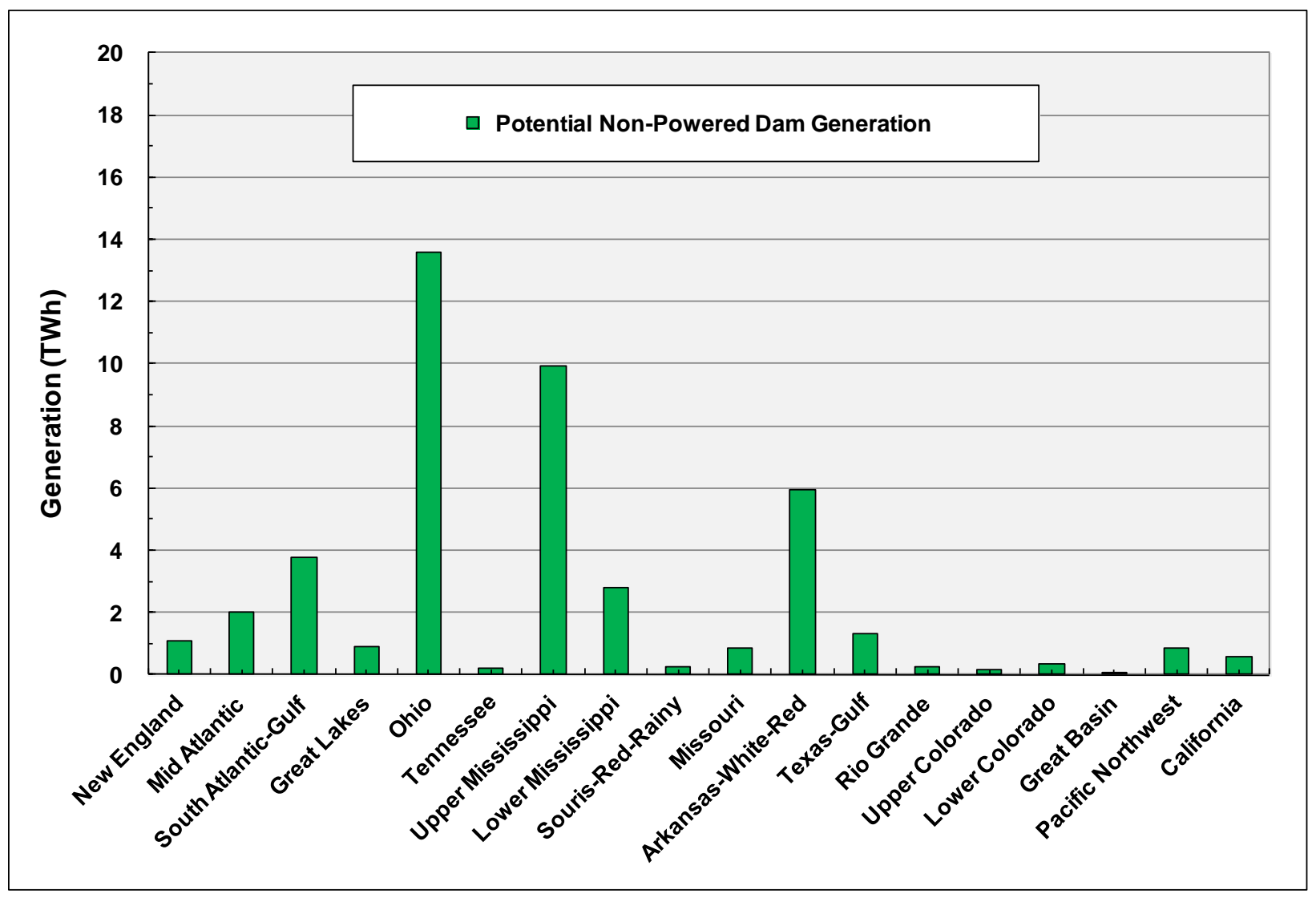

Figure 12. Potential hydropower generation from existing NPDs 

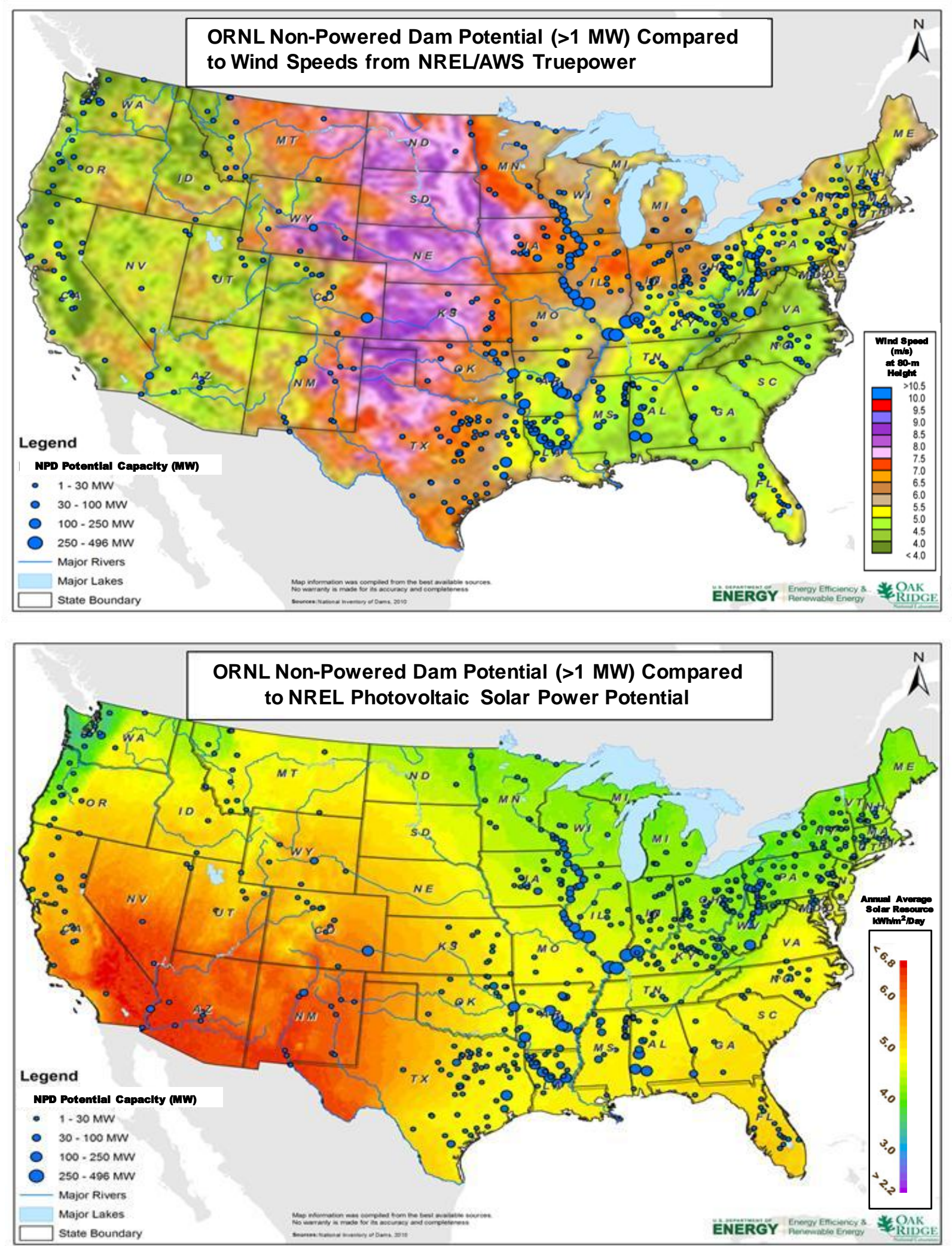

Figure 13. Comparison of top NPD sites with potential capacities greater than 1MW with maps of wind and solar photovoltaic resource potential 


\subsection{Future Improvement Opportunities}

During the execution of the NPD assessment, the study team identified several refinements that were not possible within the current scope of the effort but that may yield improved estimates. Foremost is the application of refined site development models that include economic constraints on turbine and power house capacity based on the frequency of occurrence of daily flows. Such refinement will yield estimates of energy production that are more realistic, but less than the total energy available at a site.

In the context of refined site development modeling, there are dams in high mountain regions where an alternative development scheme with a diversion penstock may yield more hydraulic head — and greater energy production - than the simple dam height or pool elevation difference modeling provides. Enhanced modeling of water availability through collaboration with USGS research efforts will yield more robust estimates that consider long-term climate variability and provide more accurate seasonal statistics and flow-duration relationships for use in energy analysis. Future efforts could examine environmental, socioeconomic, and electric power infrastructure attributes of the NPD population to estimate site feasibility and development cost in addition to potential.

\section{References}

U.S. Department of the Interior, et al. 2007. Potential Hydroelectric Development at Existing Federal Facilities, for Section 1834 of the Energy Policy Act of 2005.

Energy Information Administration (EIA). 2010. From EIA-906, EIA-920, and EIA-923 Databases. http://eia.doe.gov/cneaf/ electricity/page/eia906_920.html

Hadjerioua, B., S.-C. Kao, M. J. Sale, Y. Wei, S. K. SanthanaVannan, H. A. Shanafield III, D. P. Kaiser, R. Devarakonda, C. Odeh, G. Palanisamy and B. T. Smith. 2011. National Hydropower Asset Assessment Project. Oak Ridge National Laboratory, U.S. Department of Energy.

Hall, D. G., S. J. Cherry, K. S. Reeves, R. D. Lee, G. R. Carroll, G. L. Sommers, and K. L. Verdin. 2004. Water Energy Resources of the United States with Emphasis on Low Head/Low Power Resources, DOE/ID-11111, April 2004.

National Renewable Energy Laboratory. 2011. U.S. Solar Resource Maps (Photovoltaic). Obtained from http://www.nrel.gov/gis/solar.html

U.S. Bureau of Reclamation. 2011. Hydropower Resource Assessment at Existing Reclamation Facilities. Denver, CO. March 2011.

Simley, J. D., W. J. Carswell Jr. 2009. The National Map -Hydrography: U.S. Geological Survey Fact Sheet 2009-3054, 4p. 


\section{Acknowledgement}

The authors would like to acknowledge and express their appreciation to the following individuals and programs for their review and comment of this report. The listing of reviewers here does not imply their agreement with all findings of the report.

DOE Wind and Water Power Program:

- Michael Reed, Water Power Team Lead

- Hoyt Battey, Water Power Market Acceleration and Deployment Lead

- Rajesh Dham, P.E., Hydropower Technology Development Lead

- Gina Krump, former Support Contractor

- Alejandro Moreno, former Water Power Team Lead

Idaho National Laboratory:

- Doug Hall, Water-Energy Program Manager

Consultants:

- Michael J. Sale, M.J. Sale \& Associates

- Norman Bishop, Knight Piesold

- James Parham, Parham \& Associates

Tennessee Valley Authority:

- Charles L. Bach

- Carolyn M. Koroa

U.S. Bureau of Reclamation:

- Kerry L. McCalman

- Michael Pulskamp

- $\quad$ Erin K. Foraker

- Merlynn D. Bender

U.S. Army Corps of Engineers:

- William D. Proctor

- Andrews C. Janet

- Dowell A. Eugene

Hydropower industry reviewers and commenters:

- Dave Youlen, ECRE

- Linda Church-Ciocci, NHA

- Jeff Leahey, NHA

- Andrew Munro, NHA/GCPUD

- Rick Miller, HDR | DTA

- Dave Culligan, HDR |DTA 
- Don Erpenbeck, MWH

- Eric Van Deuren, Mead \& Hunt

Oak Ridge National Laboratory:

- Suresh K. SanthanaVannan, Informatics Specialist

- Harold A. Shanafield III, Database Management

- Ranjeet Devarakonda, Interface Development

- Dale P. Kaiser, Research Climatologist

- Maria G. Martinez, GIS Analyst

- Rocio Martinez, Ph.D., Resource Economist

- Henriette Jager, Ph.D., Fisheries Biologist

- Mark S. Bevelhimer, Ph.D., Fisheries Biologist

- Glenn F. Cada, Ph.D., Fisheries Biologist

The authors also would like to acknowledge and express their appreciation for the technical editing by Ms. Cynthia Webb and the word processing by Ms. Lindsey J. Wilson. 
Appendix A. Top 100 NPD with Hydropower Potential

\begin{tabular}{|c|c|c|c|c|c|c|c|c|c|c|c|}
\hline & & & & & & & & & Estim & $\begin{array}{l}\text { ed Annual } \\
\text { erage }\end{array}$ & \\
\hline & Dam Name & ${ }^{\star *}$ Owner name & City & County & State & River Name & $\begin{array}{c}\text { Year } \\
\text { completed }\end{array}$ & $\begin{array}{l}\text { Estimated } \\
\text { Head (feet) }\end{array}$ & $\begin{array}{l}\text { Flow } \\
\text { (cfs) }\end{array}$ & $\begin{array}{c}\text { *Generation } \\
\text { (MWh) }\end{array}$ & $\begin{array}{c}\text { Estimated } \\
\text { Potential } \\
\text { *Capacity } \\
\text { (MW) }\end{array}$ \\
\hline 1 & OHIO RIVER LOCKS \& DAM 53 & CELRL & OLMSTED & PULASKI & $\mathrm{KY} / \mathrm{IL}$ & $\mathrm{OHIO}$ & 1929 & 12.0 & 276,990 & $2,084,907$ & 496.0 \\
\hline 2 & OHIO RIVER LOCKS \& DAM 52 & CELRL & BROOKPORT & MASSAC & $\mathrm{KY} / \mathrm{IL}$ & $\mathrm{OHIO}$ & 1929 & 12.0 & 276,133 & $2,078,454$ & 494.5 \\
\hline 3 & JOHN T. MYERS LOCKS \& DAM & CELRL & UNIONTOWN & UNION & $\mathrm{KY} / \mathrm{IN}$ & $\mathrm{OHIO}$ & 1975 & 18.0 & 147,134 & $1,661,216$ & 395.2 \\
\hline 4 & NEWBURGH LOCKS \& DAM & CELRL & SCUFFLETOWN & HENDERSON & $\mathrm{KY} / \mathrm{IN}$ & $\mathrm{OHIO}$ & 1975 & 16.0 & 133,554 & $1,340,348$ & 318.9 \\
\hline 5 & MELVIN PRICE LOCKS \& DAM & CEMVS & ALTON & MADISON & $\mathrm{IL} / \mathrm{MO}$ & MISSISSIPPI & 1990 & 24.0 & 97,508 & $1,467,886$ & 299.3 \\
\hline 6 & \begin{tabular}{|l} 
COFFEEVILLE LOCK \& DAM \\
\end{tabular} & CESAM & COFFEEVILLE & CLARK & $\mathrm{AL}$ & TOMBIGBEE & 1962 & 34.0 & 26,470 & 564,511 & 241.7 \\
\hline 7 & DEMOPOLIS LOCK \& DAM & CESAM & DEMOPOLIS & MARENGO & $\mathrm{AL}$ & TOMBIGBEE & 1955 & 40.0 & 22,113 & 554,822 & 237.6 \\
\hline 8 & CLAIBORNE LOCK \& DAM & CESAM & CLAIBORNE LANDING & MONROE & AL & ALABAMA & 1969 & 30.0 & 28,340 & 533,297 & 228.3 \\
\hline 9 & RED RIVER W.W. LOCK \& DAM 03 & CEMVK & COLFAX & NATCHITOCHES & LA & RED & 1991 & 31.0 & 30,192 & 587,080 & 187.0 \\
\hline 10 & DAVID D. TERRY LOCK \& DAM & CESWL & PINE BLUFF & PULASKI & $\mathrm{AR}$ & ARKANSAS & 1968 & 18.0 & 45,857 & 517,745 & 164.9 \\
\hline 11 & JOE HARDIN LOCK \& DAM & CESWL & GRADY & LINCOLN & $\mathrm{AR}$ & ARKANSAS & 1968 & 20.0 & 48,420 & 607,436 & 161.0 \\
\hline 12 & COL CHARLES D. MAYNARD LOCK \& DAM & CESWL & REDFIELD & JEFFERSON & AR & ARKANSAS & 1968 & 17.0 & 45,970 & 490,195 & 156.1 \\
\hline 13 & LIVINGSTON DAM & $\begin{array}{l}\text { TRINITY RIVER } \\
\text { AUTHORITY }\end{array}$ & LIBERTY & SAN JACINTO & $T X$ & $\begin{array}{l}\text { TRINITY } \\
\text { RIVER }\end{array}$ & 1969 & 70.0 & 7,453 & 327,233 & 152.0 \\
\hline 14 & LOCK \& DAM 25 & CEMVS & WINFIELD & LINCOLN & $\mathrm{MO} / \mathrm{IL}$ & MISSISSIPPI & 1939 & 15.0 & 76,764 & 722,259 & 147.3 \\
\hline 15 & LOCK \& DAM 24 & CEMVS & CLARKSVILLE & PIKE & $\mathrm{MO} / \mathrm{IL}$ & MISSISSIPPI & 1940 & 15.0 & 76,366 & 718,512 & 146.5 \\
\hline 16 & TOAD SUCK FERRY LOCK \& DAM & CESWL & CONWAY & FAULKNER & AR & ARKANSAS & 1969 & 16.0 & 45,336 & 454,988 & 144.9 \\
\hline 17 & RUSSELL B. LONG LOCK \& DAM & CEMVK & GRAND ECORE & NATCHITOCHES & LA & RED & 1995 & 25.0 & 28,663 & 449,465 & 143.1 \\
\hline 18 & W.D.MAYO LOCK \& DAM & CESWT & FORT COFFEE & LE FLORE & OK & ARKANSAS & 1970 & 21.0 & 32,145 & 423,426 & 134.9 \\
\hline 19 & EMMETT SANDERS LOCK \& DAM & CESWL & PINE BLUFF & JEFFERSON & AR & ARKANSAS & 1968 & 14.0 & 46,007 & 404,007 & 128.7 \\
\hline 20 & JOE D. WAGGONNER, JR. LOCK \& DAM & CEMVK & SIMMESPORT & CATAHOULA & LA & RED & 1985 & 25.0 & 25,242 & 395,825 & 126.1 \\
\hline 21 & JOHN OVERTON LOCK \& DAM & CEMVK & SIMMESPORT & RAPIDES & LA & RED & 1987 & 24.0 & 31,322 & 471,522 & 125.0 \\
\hline 22 & JONESVILLE LOCK \& DAM & CEMVK & SIMMESPORT & CATAHOULA & LA & BLACK & 1972 & 30.0 & 24,577 & 462,472 & 122.6 \\
\hline 23 & MILLWOOD DAM & CESWL & ASHDOWN & LITTLE RIVER & AR & LITTLE & 1966 & 74.0 & 6,818 & 316,458 & 100.8 \\
\hline 24 & MONTGOMERY LOCKS \& DAM & CELRP & MONACA & BEAVER & PA & $\mathrm{OHIO}$ & 1936 & 18.0 & 37,166 & 419,626 & 99.8 \\
\hline 25 & MISSISSIPPI RIVER DAM 22 & CEMVR & SAVERTON & RALLS & $\mathrm{MO} / \mathrm{IL}$ & MISSISSIPPI & 1938 & 10.0 & 74,224 & 465,570 & 94.9 \\
\hline
\end{tabular}

*Estimated Generation and Capacity are based on the total energy available at the site.

**Legend for Owner Name column is located in Appendix B. 
Appendix A. Top 100 NPD with Hydropower Potential (26 to 50)

\begin{tabular}{|c|c|c|c|c|c|c|c|c|c|c|c|}
\hline & \multirow[b]{2}{*}{ Dam Name } & \multirow[b]{2}{*}{${ }^{* *}$ Owner name } & \multirow[b]{2}{*}{ City } & \multirow[b]{2}{*}{ County } & \multirow[b]{2}{*}{ State } & \multirow[b]{2}{*}{ River Name } & \multirow[b]{2}{*}{$\begin{array}{c}\text { Year } \\
\text { completed }\end{array}$} & \multirow[b]{2}{*}{$\begin{array}{l}\text { Estimated } \\
\text { Head (feet) }\end{array}$} & \multicolumn{2}{|c|}{$\begin{array}{c}\text { Estimated Annual } \\
\text { Average }\end{array}$} & \multirow[b]{2}{*}{$\begin{array}{c}\text { Estimatec } \\
\text { Potential } \\
{ }^{*} \text { Capacity } \\
\text { (MW) }\end{array}$} \\
\hline & & & & & & & & & $\begin{array}{l}\text { Flow } \\
\text { (cfs) }\end{array}$ & $\begin{array}{l}\text { *Generation } \\
\text { (MWh) }\end{array}$ & \\
\hline 26 & MISSISSIPPI RIVER DAM 21 & CEMVR & QUINCY & ADAMS & $\mathrm{MO} / \mathrm{IL}$ & MISSISSIPPI & 1938 & 10.0 & 72,781 & 456,518 & 93.1 \\
\hline 27 & MONTGOMERY POINT LOCK \& DAM & CESWL & WATSON & DESHA & $A R$ & WHITE & 2004 & 20.0 & 27,982 & 351,041 & 93.0 \\
\hline 28 & MISSISSIPPI RIVER DAM 20 & CEMVR & CANTON & LEWIS & $\mathrm{MO} / \mathrm{IL}$ & MISSISSIPPI & 1936 & 10.0 & 72,126 & 452,410 & 92.2 \\
\hline 29 & LOCK \& DAM 15 & CEMVR & ROCK ISLAND & ROCK ISLAND & $\mathrm{IL} / \mathrm{IA}$ & MISSISSIPPI & 1934 & 16.0 & 42,841 & 429,950 & 87.7 \\
\hline 30 & EMSWORTH LOCKS \& DAMS & CELRP & PITTSBURGH & ALLEGHENY & PA & $\mathrm{OHIO}$ & 1938 & 18.0 & 31,424 & 354,796 & 84.4 \\
\hline 31 & JOHN MARTIN DAM \& RESERVOIR & CESPA & LAS ANIMAS & BENT & $\mathrm{CO}$ & ARKANSAS & 1943 & 78.5 & 5,027 & 247,622 & 78.9 \\
\hline 32 & LOCK \& DAM 18 & CEMVR & GLADSTONE & HENDERSON & $\mathrm{IL} / \mathrm{IA}$ & MISSISSIPPI & 1937 & 10.0 & 54,831 & 343,930 & 70.1 \\
\hline 33 & DUBUQUE NUMBER 11 & $\begin{array}{l}\text { DAEN NCR } \\
\text { (CORPS OF } \\
\text { ENGR) }\end{array}$ & DUBUQUE & DUBUQUE & IA & MISSISSIPPI & 1937 & 12.0 & 44,801 & 337,215 & 68.8 \\
\hline 34 & RED ROCK DAM & CEMVR & KNOXVILLE & MARION & IA & DES MOINES & 1969 & 104.0 & 4,995 & 325,849 & 66.4 \\
\hline 35 & MISSISSIPPI RIVER DAM 13 & CEMVR & CLINTON & WHITESIDE & $\mathrm{IA} / \mathrm{IL}$ & MISSISSIPPI & 1939 & 11.0 & 46,987 & 324,201 & 66.1 \\
\hline 36 & OOLOGAH LAKE & CESWT & CLAREMORE & ROGERS & OK & VERDIGRIS & 1963 & 86.0 & 3,502 & 188,933 & 60.2 \\
\hline 37 & MISSISSIPPI RIVER DAM 14 & CEMVR & LECLAIRE & SCOTT & $\mathrm{IA} / \mathrm{IL}$ & MISSISSIPPI & 1939 & 11.0 & 42,773 & 295,121 & 60.2 \\
\hline 38 & MISSISSIPPI RIVER DAM 16 & CEMVR & MUSCATINE & ROCK ISLAND & $\mathrm{IA} / \mathrm{IL}$ & MISSISSIPPI & 1937 & 9.0 & 48,050 & 271,253 & 55.3 \\
\hline 39 & GEORGE W ANDREWS LOCK \& DAM & CESAM & GORDON & HOUSTON & $\begin{array}{l}\mathrm{AL} / \\
\mathrm{GA}\end{array}$ & $\begin{array}{c}\text { CHATTAHOO } \\
\text { CHEE }\end{array}$ & 1963 & 25.0 & 8,203 & 128,638 & 55.1 \\
\hline 40 & PALO VERDE DIVERSION & $\mathrm{DOI} B \mathrm{R}$ & MAYFLOWER & YUMA, & $\begin{array}{l}\mathrm{AZI} / \\
\mathrm{CA}\end{array}$ & COLORADO & 1957 & 46.0 & 5,603 & 161,670 & 54.3 \\
\hline 41 & WILLIAM BACON OLIVER REPLACEMENT & CESAM & TUSCALOOSA & TUSCALOOSA & $\mathrm{AL}$ & $\begin{array}{c}\text { BLACK } \\
\text { WARRIER } \\
\end{array}$ & 1992 & 28.0 & 7,159 & 125,742 & 53.8 \\
\hline 42 & MISSISSIPPI RIVER DAM 12 & CEMVR & BELLEVUE & JACKSON & $\mathrm{IA} / \mathrm{IL}$ & MISSISSIPPI & 1938 & 9.0 & 45,165 & 254,971 & 52.0 \\
\hline 43 & COLUMBIA LOCK \& DAM & CEMVK & RIVERTON & CALDWELL & LA & OUACHITA & 1970 & 18.0 & 17,301 & 195,334 & 51.8 \\
\hline 44 & A.I.SELDEN & CESAM & EASTPORT & HALE & AL & $\begin{array}{c}\text { BLACK } \\
\text { WARRIOR }\end{array}$ & 1958 & 22.0 & 8,625 & 119,016 & 51.0 \\
\hline 45 & MISSISSIPPI RIVER DAM 17 & CEMVR & NEW BOSTON & MERCER & $\mathrm{IA} / \mathrm{IL}$ & MISSISSIPPI & 1939 & 8.0 & 48,144 & 241,588 & 49.3 \\
\hline 46 & JOHN C. STENNIS & CESAM & COLUMBUS & LOWNDES & MS & TOMBIGBEE & 1978 & 27.0 & 6,588 & 111,567 & 47.8 \\
\hline 47 & DASHIELDS LOCKS \& DAM & CELRP & CORAPOLIS & ALLEGHENY & PA & $\mathrm{OHIO}$ & 1929 & 10.0 & 31,559 & 197,956 & 47.1 \\
\hline 48 & TYGART DAM & CELRP & GRAFTON & TAYLOR & WV & TYGART & 1938 & 133.5 & 2,360 & 197,513 & 47.0 \\
\hline 49 & LOCK \& DAM 08 & CEMVP & GENOA & VERNON & $\begin{array}{l}\mathrm{WI/} \\
\mathrm{MN}\end{array}$ & MISSISSIPPI & 1937 & 11.0 & 32,842 & 226,599 & 46.2 \\
\hline 50 & BLUESTONE DAM & CELRH & HINTON & SUMMERS & wV & NEW & 1947 & 48.0 & 6,255 & 188,328 & 44.8 \\
\hline
\end{tabular}

*Estimated Generation and Capacity are based on the total energy available at the site.

**Legend for Owner Name column is located in Appendix B. 


\section{Appendix A. Top 100 NPD with Hydropower Potential (51 to 75)}

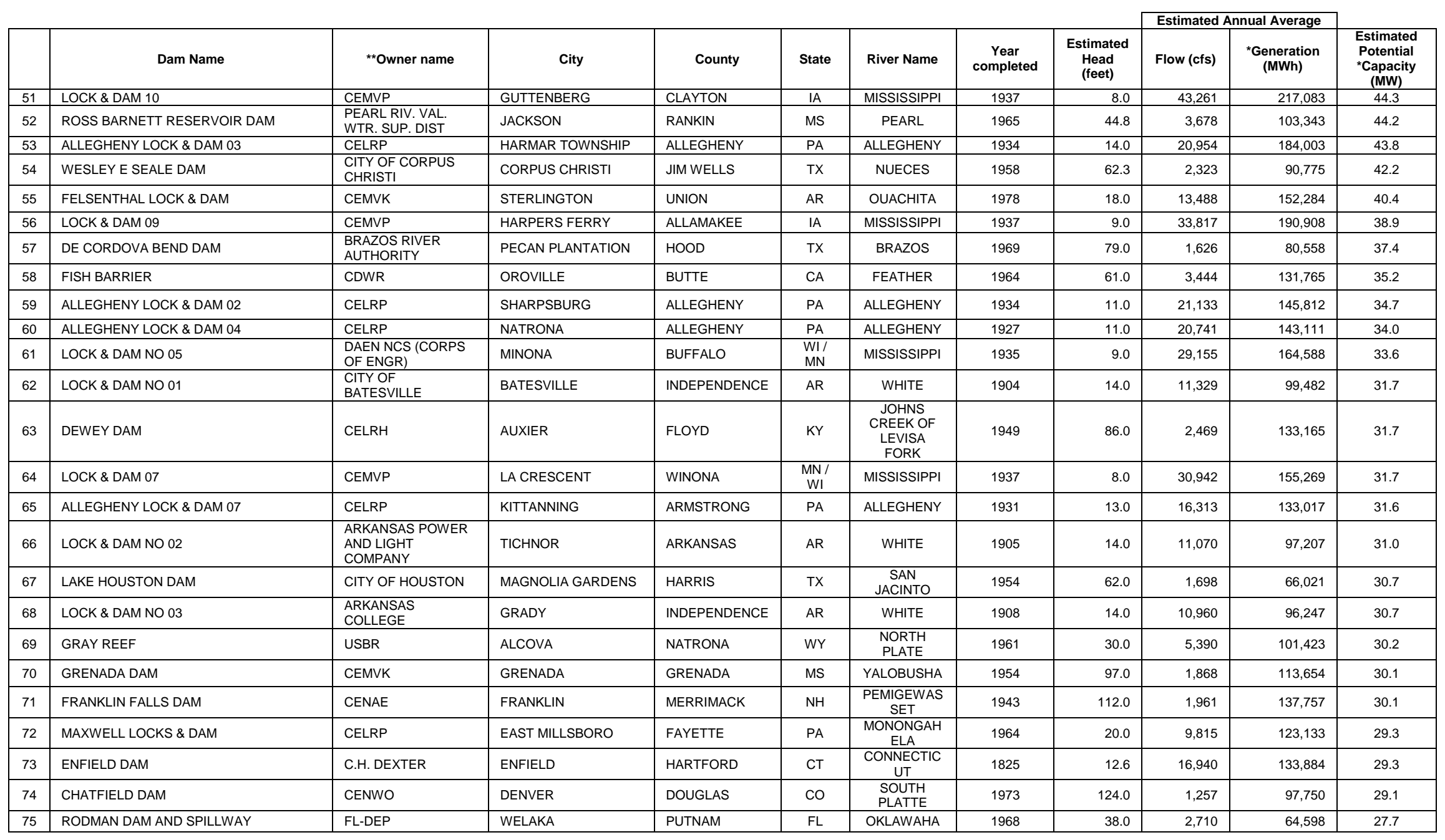

*Estimated Generation and Capacity are based on the total energy available at the site.

**Legend for Owner Name column is located at in Appendix B. 
Appendix A. Top 100 NPD with Hydropower Potential (76 to 100)

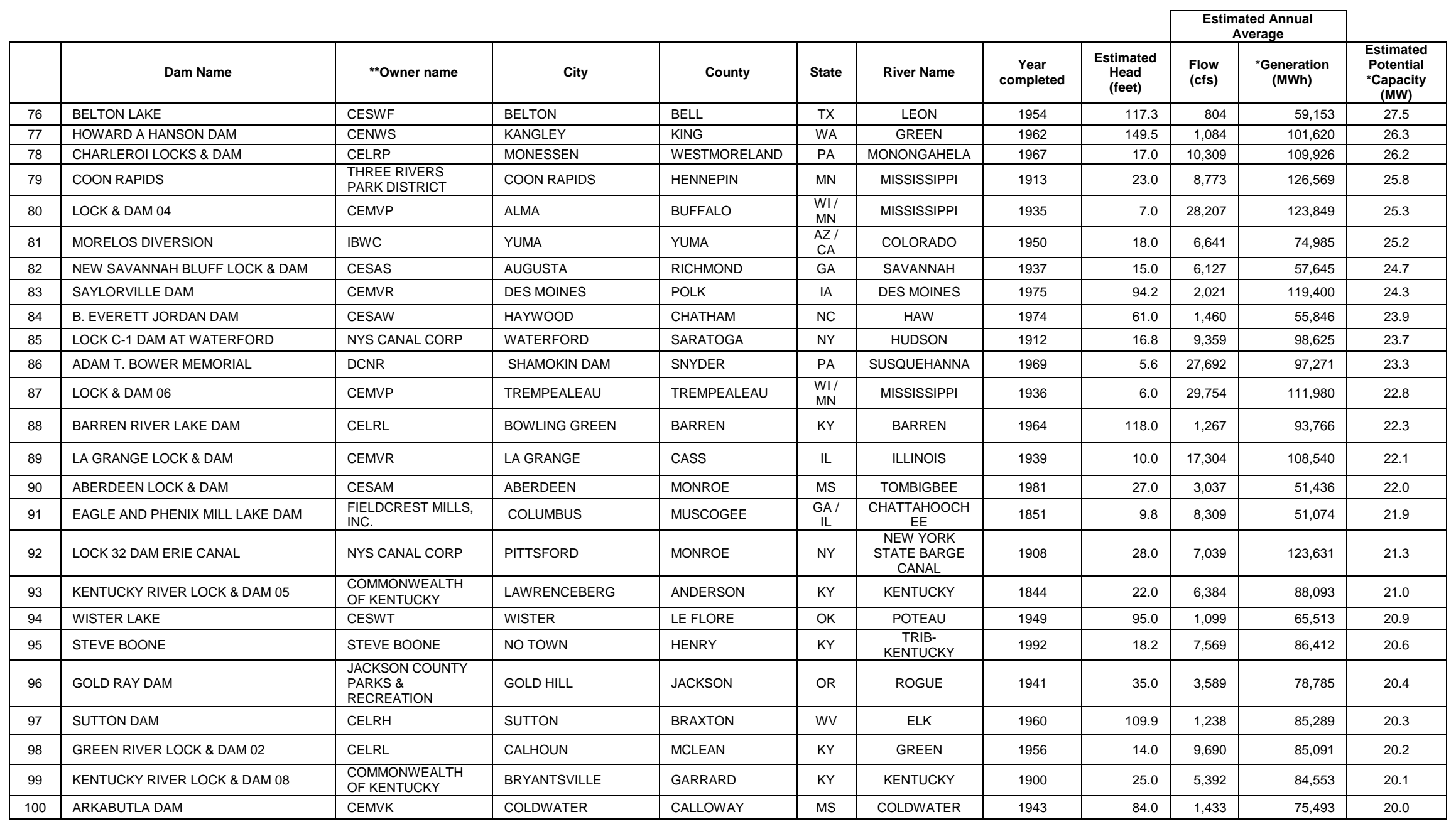

*Estimated Generation and Capacity are based on the total energy available at the site.

**Legend for Owner Name column is located in Appendix B. 


\section{Appendix B. Acronyms}

\begin{tabular}{|c|c|}
\hline CDWR & California Department of Water Resources \\
\hline CENAB & Corps of Engineers North Atlantic Baltimore District \\
\hline CENAN & Corps of Engineers North Atlantic New York District \\
\hline CENAO & Corps of Engineers North Atlantic Norfolk District \\
\hline CENAP & Corps of Engineers North Atlantic Philadelphia District \\
\hline CENAE & Corps of Engineers North Atlantic New England District \\
\hline CENAU & Corps of Engineers North Atlantic Europe District \\
\hline CENWK & Corps of Engineers Northwestern Kansas District \\
\hline CENWO & Corps of Engineers Northwestern Omaha District \\
\hline CENWP & Corps of Engineers Northwestern Portland District \\
\hline CENWS & Corps of Engineers Northwestern Seattle District \\
\hline CENWW & Corps of Engineers Northwestern Walla Walla District \\
\hline CEPOA & Corps of Engineers Pacific Ocean Alaska District \\
\hline CEPOF & Corps of Engineers Pacific Ocean Far East District \\
\hline $\mathrm{CEPOH}$ & Corps of Engineers Pacific Ocean Honolulu District \\
\hline CEPOJ & Corps of Engineers Pacific Ocean Japan District \\
\hline CESAC & Corps of Engineers South Atlantic Charleston District \\
\hline CESAJ & Corps of Engineers South Atlantic Jacksonville District \\
\hline CESAM & Corps of Engineers South Atlantic Mobile District \\
\hline CESAS & Corps of Engineers South Atlantic Savannah District \\
\hline CESAW & Corps of Engineers South Atlantic Wilmington District \\
\hline CESPA & Corps of Engineers South Pacific Albuquerque District \\
\hline CESPL & Corps of Engineers South Pacific Los Angeles District \\
\hline CESPK & Corps of Engineers South Pacific Sacramento District \\
\hline
\end{tabular}




\begin{tabular}{|c|c|}
\hline CESPN & Corps of Engineers South Pacific San Francisco District \\
\hline CESWF & Corps of Engineers Southwestern Forth Worth District \\
\hline CESWG & Corps of Engineers Southwestern Galveston District \\
\hline CESWL & Corps of Engineers Southwestern Little Rock District \\
\hline CESWT & Corps of Engineers Southwestern Tulsa District \\
\hline CELRB & Corps of Engineers Great Lakes and Ohio River Buffalo District \\
\hline CELRC & Corps of Engineers Great Lakes and Ohio River Chicago District \\
\hline CELRE & Corps of Engineers Great Lakes and Ohio River Detroit District \\
\hline CELRH & Corps of Engineers Great Lakes and Ohio River Huntington District \\
\hline CELRL & Corps of Engineers Great Lakes and Ohio River Louisville District \\
\hline CELRN & Corps of Engineers Great Lakes and Ohio River Nashville District \\
\hline CELRP & Corps of Engineers Great Lakes and Ohio River Pittsburgh District \\
\hline CEGRC & Corps of Engineers Gulf Region Central District \\
\hline CEGRN & Corps of Engineers Gulf Region North District \\
\hline CEGRS & Corps of Engineers Gulf Region South District \\
\hline CEMVM & Corps of Engineers Mississippi Valley Memphis District \\
\hline CENVN & Corps of Engineers Mississippi Valley New Orleans District \\
\hline CEMVR & Corps of Engineers Mississippi Valley Rock Island District \\
\hline CEMVS & Corps of Engineers Mississippi Valley St. Louis District \\
\hline CEMVP & Corps of Engineers Mississippi Valley St. Paul District \\
\hline CEMVK & Corps of Engineers Mississippi Valley Vicksburg District \\
\hline DOE & Department of Energy \\
\hline DOI & U.S. Department of the Interior \\
\hline DOI BR & U.S. Department of the Interior Bureau of Reclamation \\
\hline DWNS & Dams With Negligible Streamflow \\
\hline ECRE & Eagle Creek Renewable Energy \\
\hline
\end{tabular}




\begin{tabular}{|c|c|}
\hline EIA & Energy Information Administration \\
\hline FERC & Federal Energy Regulatory Commission \\
\hline HU & Hydrologic Unit \\
\hline NED & National Elevation Dataset \\
\hline NHA & National Hydropower Association \\
\hline NHAAP & National Hydropower Asset Assessment Project \\
\hline NHD & National Hydrography Dataset \\
\hline NID & National Inventory of Dams \\
\hline NLCD & National Land Cover Dataset \\
\hline NPD & National Non-Powered Dam \\
\hline NREL & National Renewable Energy Laboratory \\
\hline NWIS & National Water Information System \\
\hline ORNL & Oak Ridge National Laboratory \\
\hline $\mathrm{P}$ & Precipitation \\
\hline Q & Runoff \\
\hline TVA & Tennessee Valley Authority \\
\hline USACE & U.S. Army Corps of Engineers \\
\hline USBR & U.S. Bureau of Reclamation (or, Reclamation) \\
\hline USGS & U.S. Geological Survey \\
\hline WBD & Watershed Boundary Dataset \\
\hline
\end{tabular}




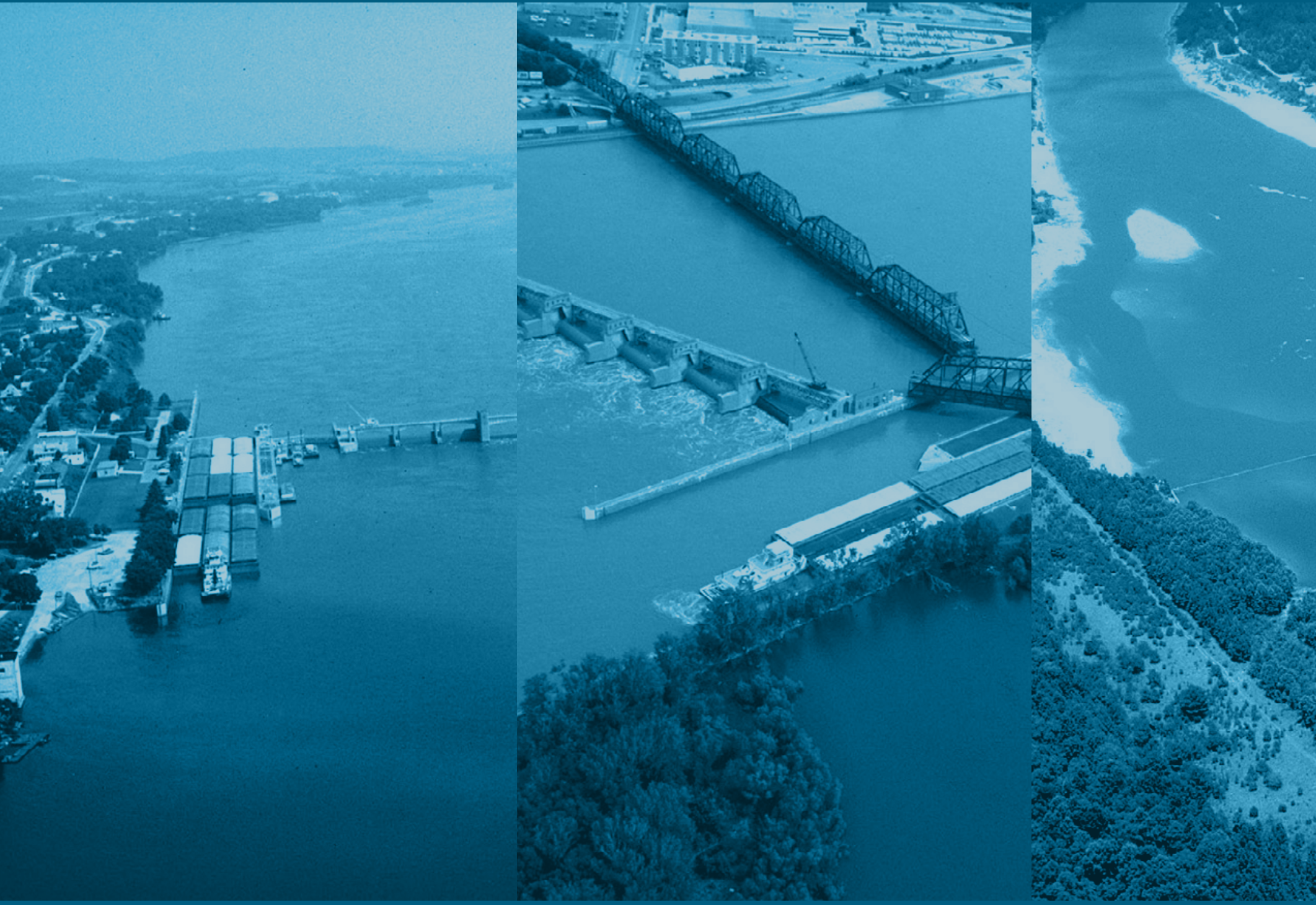

\section{a. \\ ENERGY}

Energy Efficiency \& Renewable Energy
GPO DOE/EE-0711 • April 2012

Printed with a renewable-source ink on paper containing at least 50\% wastepaper, including $10 \%$ post consumer waste. 